ROCZNIKI HISTORYCZNE

Rocznik LXXXI - 2015

ANNA HORECZY (Warszawa)

\title{
Prawnicze doktoraty Polaków w Bolonii w XV wieku
}

\section{WPROWADZENIE}

Polakom obecnym na uniwersytetach prawniczych w Bolonii w XV w. poświęcono już wiele prac, których autorzy zajmowali się głównie identyfikacją studiujących osób, podczas gdy przebieg ich studiów prawniczych (w wielu przypadkach hipotetyczny) i sposób zdobywania stopnia naukowego nie doczekały się pogłębionej analizy ${ }^{1}$. Celem niniejszego artykułu jest charakterystyka grupy Polaków, którzy uzyskali w Bolonii licencjat lub doktorat z prawa w XV w., i zwrócenie uwagi na różne sposoby uzyskiwania tych stopni (kiedy mamy do czynienia z pełnymi studiami, a kiedy tylko z przyjazdem do Bolonii po stopień naukowy), a także próba pokazania, w przypadku których osób można mówić o bolońskiej formacji prawniczej - przez co rozumieć należy zdobycie określonej wiedzy prawniczej wykorzystywanej potem w praktyce, doświadczeń, nawyków, odwoływanie się do określonych autorytetów prawnych pod wpływem studiów pod kierunkiem bolońskich profesorów, nauczających w określony sposób i korzystających z podobnego zestawu komentarzy. Przyjęte ramy chronologiczne, obejmujące lata 1400-1499, pozwolą prześledzić ewolucję modelu studiowania i umożliwią pokazanie pewnych trendów w poszczególnych okresach. Przedmiotem naszego zainteresowania będzie w szczególności wpływ graduatów bolońskich na krakowskie środowisko uniwersyteckie.

${ }^{1}$ Praca wykonana w ramach projektu pt. „Recepcja włoskiej kultury intelektualnej w krakowskim środowisku uniwersyteckim od około drugiej połowy XIV wieku do końca XV wieku", finansowanego ze środków Narodowego Centrum Nauki przyznanych na podstawie decyzji numer DEC-2012/07/N/HS3/00514. W tekście zastosowano następujące skróty: ASB - Archivio di Stato di Bologna; BP - Bullarium Poloniae, wyd. I. Sułkowska-Kuraś, S. Kuraś, t. III-VII, Romae-Lublini 1988-2006; DBI - Dizionario biografico degli Italiani; LC 1378-1420 - Liber secretus iuris caesarei dell università di Bologna, wyd. A. Sorbelli, t. I: 1378-1420, Bologna 1938; LC 1421-1450 - Liber secretus iuris caesarei dell'Università di Bologna, wyd. A. Sorbelli, t. II: 1421-1450 con una introduzione sull'esame nell'Università durante il Medioevo, Bologna 1942; LC 1451-1500 - C. P i a n a, Il „Liber secretus iuris caesarei” dell'università di Bologna 1451-1500, Milano 1984; LP - Liber secretus iuris pontifici dell'università di Bologna 1451-1500, wyd. C. Piana, Milano 1989; MUK - Metryka Uniwersytetu Krakowskiego z lat 1400-1508. Biblioteka Jagiellońska rkp. 258, t. I, Kraków 2004; NKP - Najstarsza księga promocji Wydziału Sztuk Uniwersytetu Krakowskiego z lat 1402-1541, wyd. A. Gąsiorowski, T. Jurek, I. Skierska, Warszawa 2011; Statuti - Statuti delle Università e dei Collegi dello Studio Bolognese, wyd. C. Malagola, Bologna 1888; PSB - Polski słownik biograficzny. 
Badania nad bolońskimi studiami Polaków zapoczątkowane zostały w połowie XIX w. antykwaryczną pracą Aleksandra Przeździeckiego². Pierwszy katalog Polaków studiujących w Bolonii stworzył historyk Uniwersytetu Bolońskiego Carlo Malagola ${ }^{3}$. Badania archiwalne nad tym tematem prowadził pod koniec XIX w. również historyk literatury Stanisław Windakiewicz ${ }^{4}$. Systematyczne i dokładne kwerendy w Bolonii przeprowadził w tym czasie również Jan Fijałek, a ich wyniki dla pierwszej połowy XV w. zostały opublikowane w niezastąpionej dotąd pracy poświęconej Polakom studiującym we Włoszech ${ }^{5}$. Syntetyczny przegląd związków Polaków z Bolonią dał Stanisław $\mathrm{Kot}^{6}$. Podobny charakter ma praca Ryszarda Lewańskiego zawierająca katalog Polaków studiujących na uniwersytecie bolońskim, oparty na dawniejszej literaturze przedmiotu, który jednak w świetle obecnych badań nie może być przyjęty bez zastrzeżeń. Autor omówił też krótko, na kilku wybranych przykładach, studia prawników polskich w Bolonii od XIV do XVI w. ${ }^{7}$ Nowe informacje o Polakach (do których zaliczeni zostali także Ślązacy) studiujących w Bolonii w XIII i XIV w. przyniosły artykuły Adama Vetulaniego i Zofii Kozłowskiej-Budkowej ${ }^{8}$, oparte na wydawnictwach źródłowych ${ }^{9}$. Kolejne studia poświęcone Polakom w Bolonii publikowano w związku z sześćsetleciem Uniwersytetu Jagiellońskiego ${ }^{10}$ oraz dziewięćsetleciem Uniwersytetu Bolońskiego ${ }^{11}$.

${ }^{2}$ A. Przeździ e c ki, O Polakach w Bononii i Padwie, Warszawa 1853.

${ }^{3}$ C. M a la g o la, I Polacchi in Bologna, w: Bologna. Album storico, Bologna 1882, s. $17-38$.

${ }^{4}$ S. W i n d a k i e w i c z, Bolonia i Polska, Przegląd Polski 22, 1888, t. 88, z. 10, s. 1-73; t e n że, Informacja o aktach uniwersytetu bolońskiego, w: Archiwum do dziejów literatury i oświaty w Polsce, t. VII, Kraków 1892, s. 130-148; por. też t e n ż e, Materiały do historii Polaków w Padwie, w: tamże, s. 149-185.

5 J. F i j ał e k, Polonia apud Italos scholastica saeculum XV, z. 1, Cracoviae 1900.

${ }^{6} \mathrm{~S}$. K o t, Le relazioni secolari della Polonia con la Bologna. Conferenza tenuta il 9 gennaio 1948 nell'Accademia delle Scienze dell'Istituto di Bologna, Bologna 1949.

${ }^{7}$ R. L e w a ń s k i, Storia delle relazioni fra la Polonia e Bologna, Bologna 1951.

${ }^{8}$ Z. K o złow s ka-B udk ow a, Polonia w Bolonii w latach 1300-1327, w: Cultus et cognitio. Studia z dziejów średniowiecznej kultury, Warszawa 1976, s. 281-292; A. Ve t u 1 a n i, Z badań nad Polakami w średniowiecznej Bolonii, w: tamże, s. 611-619.

${ }^{9}$ Chartularium studii Bononiensis, t. I-XV, Bologna 1909-1987; G. T a m b a, Chartularium Studii Bononiensis. Riflessioni su un'esperienza quasi secolare, w: La storia delle università italiane. Archivi, fonti, indirizzi di ricerca, Trieste 1996, s. 171-180; Acta nationis Germanicae Universitatis Bononiensis, wyd. F. Friedlaender, C. Malagola, Berolini 1887.

${ }^{10}$ Dla uczczenia tej rocznicy Uniwersytet Boloński wydał tom: Monumenta Polonorum Bononiensia, Bologna 1964, w którym zamieszczony został wykaz chronologiczny Polaków którzy studiowali i/lub zdobyli stopień doktorski w Bolonii od 1180 r. Lista ta zawiera wiele błędów i nieścisłości, zwłaszcza w zakresie identyfikacji osób. Niewłaściwym rozwiązaniem, które może tylko identyfikację tę utrudniać, było podawanie imion Polaków w wersji włoskiej, a nie łacińskiej. Na przykład podany tam (s. 47) „1388 Giovanni de Brzorzinch (Jan Brożek)”, to w rzeczywistości Johannes de Borsnicz wymieniony jako doktor dekretów w BP III, nr 113, 181.

${ }^{11}$ Krótkie biogramy Polaków studiujących w Bolonii do 1364 r. dały Z. K o zło w s k a - B u d k ow a, C. Z a w o d z i ń s k a, I primi studenti polacchi all'università di Bologna (fino al 1364), w: Commentationes historicae Almae Matri Studiorum Bononiensi novem secula feliciter celebranti ab Universitate Iagellonica Cracoviensi oblatae, Cracovia 1988, s. 27-48. Próbę rekonstrukcji listy Polaków studiujących w Bolonii od XII do XVIII w. i związane z tym problemy przedstawia R. L e w ański, La matricola degli scolari polacchi a Bologna: un 
W ostatnich latach wznowione zostały badania prozopograficzne nad studiującymi w Bolonii Polakami, zwłaszcza dla okresu od drugiej połowy XV w. Nowe ustalenia związane z identyfikacją polskich graduatów w dobie wczesnonowożytnej dał Marian Chachaj $^{12}$, a szczególnie cenne są badania Stanisława A. Sroki, który przedstawił wykaz Polaków wypromowanych na uniwersytetach w Bolonii w drugiej połowie $\mathrm{XV}$ w., opierając się także na źródłach niewykorzystywanych dotąd przez badaczy ${ }^{13}$.

Informacji na temat trybu studiowania i uzyskiwania stopni naukowych prawa kanonicznego i cywilnego w Bolonii w XV w. dostarczają statuty bolońskiego uniwersytetu prawników z 1432 r. wraz ze zmianami wprowadzonymi w 1459 r. i później ${ }^{14}$. Z czternastowiecznych statutów (od 1317 do 1347 r.) znany jest tylko fragment ${ }^{15}$. O sprawach tych mówią także statuty kolegium doktorów prawa cywilnego z 1397 z późniejszymi uzupełnieniami oraz statuty kolegium doktorów prawa kanonicznego z 1460 r. ${ }^{16}$ Statuty są źródłami normatywnymi i nie wiadomo, w jakim stopniu odzwierciedlają realia studiowania ${ }^{17}$. Nie można też zakładać, że postanowienia w nich zawarte odnoszą się do całej epoki. Dopiero przeprowadzenie szczegółowych badań przy wykorzystaniu wszystkich zachowanych źródeł pozwoliłoby na dokładne przedstawienie trybu studiowania na danym uniwersytecie ${ }^{18}$.

tentativo di ricostruzione e di analisi, w: Laudatio Bononiae, Bologna-Varsavia 1990, s. 127166. Problemy metodologiczne związane $\mathrm{z}$ badaniem obecności studentów polskich w Bolonii i Padwie poruszyła L. R o s s e tti, Spunti per la storia degli scolari polacchi a Bologna e a Padova, w: tamże, s. 244-251, która zasygnalizowała również, jak zmieniały się preferencje związane $\mathrm{z}$ wyborem jednego z tych dwóch ośrodków wraz z upływem czasu i w zależności od wybieranego kierunku studiów.

${ }^{12} \mathrm{M}$. Ch a c haj, Promocje doktorskie biskupów, prałatów i kanoników katedralnych krakowskich na Uniwersytecie Bolońskim od schyłku XV do końca XVII wieku, w: Kościół katolicki w Małopolsce w średniowieczu i we wczesnym okresie nowożytnym, Kielce-Gdańsk 2001, s. 439-453.

${ }_{13}$ S. A. S r o k a, Academic degrees obtained by Poles studying at northern Italian universities in the second half of the 15th c. (Bologna, Padua, Ferrara), Annali di storia delle università italiane 2013, s. 325-331; t e n że, Polacy w Bolonii u schyłku średniowiecza w świetle diariusza Gaspare Codibó z lat 1471-1504, w: Memoria viva. Studia historyczne poświęcone pamięci Izabeli Skierskiej (1967-2014), Warszawa-Poznań 2015, s. 667-676; t e n ż e, Wykaz Polaków wypromowanych na uniwersytecie w Bolonii w drugiej połowie XV w., Kwartalnik Historyczny 121, 2014, nr 1, s. 133-155.

14 Statuti, s. 47-209.

15 Zachowany fragment nie dotyczy trybu ani lat studiowania koniecznych do uzyskania stopnia naukowego (Statuti, s. 1-44). Znane są statuty uniwersytetu prawniczego w Padwie z 1331 r., wzorowane na statutach bolońskich; wydał je H. D e n if l e, Die Statuten der Juristen-Universität zu Padua vom Jahre 1331, Archiv für Literatur- und Kirchengeschichte des Mittelalters 6, 1892, s. 379-357; zob. D. G i r g e n s o h n, Gli statuti medioevali delle Università di giurisprudenza italiane: conservazione, materie regolate, interdipendenze, w: Università in Europa. Le istituzioni universitarie dal Medio Evo ai nostri giorni. Strutture, organizzazione, funzionamento, Soveria Mannelli 1995, s. 161.

${ }_{16}$ Statuti, s. 327-421.

17 D. Girge n s o h n, Gli statuti medioevali, s. 160.

${ }^{18}$ A. B e 11 o n i, L'insegnamento giuridico nelle università italiane, w: Luoghi e metodi di insegnamento giuridico nell'Italia medievale (secoli XII-XIV), Galatina 1989, s. 143, wskazuje na brak takich badań i powielanie w wielu opracowaniach uogólnionych modeli studiowania zbudowanych na podstawie znajomości statutów oraz na częste zakładanie przez badaczy, 
Informacji o przebiegu studiów i egzaminów dostarczają przede wszystkim Libri secreti - księgi prowadzone przez przewodniczących kolegium doktorów, osobno dla prawa kanonicznego i dla prawa cywilnego ${ }^{19}$. Dla prawa kanonicznego zachowała się księga zawierająca wpisy od 1377 r. ${ }^{20}$, której część z lat 1450-1500 (tylko fragmenty dotyczące egzaminów) została wydana drukiem ${ }^{21}$. Część pierwsza natomiast, obejmująca lata 1377-1414, jest kopią prowadzonych na bieżąco wpisów, powstałą na zlecenie przewodniczącego kolegium doktorów Geremii Angelellego ${ }^{22}$. Dla prawa cywilnego Liber secretus zachował się od $1378 \mathrm{r}$. i został wydany drukiem do $1500 \mathrm{r}^{23}$ Źródło to posiada w pewnych okresach luki ${ }^{24}$. Zawarte w tych księgach informacje uzupełnia dla lat 1419-1434 Liber sapientium - zbiór akt kolegium doktorów zarówno prawa kanonicznego, jak i cywilnego, a także sztuk i medycyny, spisany przez notariusza archidiakona bolońskiego. Liber sapientium wnosi dodatkowe informacje, pozwalające zidentyfikować kandydatów przystępujących do egzaminu - precyzuje imię, dostarcza dokładniejszych informacji o miejscu pochodzenia, rodzie, czasem podaje dane dotyczące ojca kandydata ${ }^{25}$. Dodatkowym źródłem są także rejestry notarialne, które dla prawa kanonicznego zaczynają się od 1431, a dla prawa cywilnego od $1483 \mathrm{r}^{26}$

Nie mamy natomiast dla piętnastowiecznej Bolonii (i wielu innych włoskich uniwersytetów) ksiąg immatrykulacji, szczególnie cennych z punktu widzenia szukania polskich studentów ${ }^{27}$. Brak ten zastępuje częściowo istnienie innych kategorii przekazów. Wykładowcy w studium bolońskim (także studenci prowadzący wykłady) wymieniani są w spisach wykładów (rotuli) zachowanych od 1384 r. ${ }^{28}$ Wśród nich, obok przedstawicieli innych nacji, znajdują się także Polacy. Niezbyt wielu Polaków

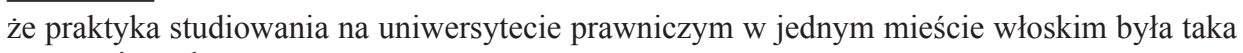
sama w innych.

${ }^{19}$ C. P i a n a, Lauree in diritto civile e canonico conferite dall'Università di Bologna secondo la relazione del „Liber sapientum” (1419-1434), Atti e memorie della deputazione della Storia Patria per le province di Romagna 17-19, 1969, s. 265.

${ }^{20}$ ASB, Studio 126.

${ }^{21}$ C. P i a n a, Introduzione, w: LP 1421-1450, s. 3.

22 ASB, Studio 126, k. 41v. Za wskazanie tego źródła dziękuję profesorowi Berardowi Pio z Dipartimento di Storia Culture Civiltà, Università di Bologna, który przygotowuje edycję części z lat 1377-1414.

${ }^{23}$ LC 1378-1420; LC 1421-1450; LC 1451-1500.

${ }^{24} \mathrm{~Np}$. w okresach maj-czerwiec i listopad-grudzień 1462, marzec-kwiecień 1467, lipiecsierpień 1468, marzec-kwiecień i listopad-grudzień 1469, lipiec-sierpień, listopad-grudzień 1477, styczeń-luty 1478, styczeń-luty 1483 (C. P i a n a, Introduzione, w: LC 1451-1500, s. 5-6).

${ }^{25}$ C. $\mathrm{P}$ i a $\mathrm{n}$ a, Lauree in diritto, s. 267-269; Liber sapientium (1419-1434), ASB, Studio, Arcidiacono 1.

${ }^{26}$ ASB, Studio 18 (Registri d'atti del collegio canonico), 26 (Registri d'atti del collegio civile); por. S. A. S ro k a, Dyplom doktorski Uniwersytetu Bolońskiego z 1472 r., Studia Źródłoznawcze 50, 2012, s. 66.

${ }^{27}$ A. L. Tro m b e t t i - B u d r i e s i, L'esame di laurea presso lo Studio bolognese. Laureati in diritto civile nel secolo XV, w: Studenti e università degli studenti. Dal XII al XIX secolo, Bologna 1988, s. 139.

${ }^{28}$ U. D a 11 a r i, I rotuli dei lettori legisti e artisti dello studio bolognese dal 1384 al 1799 , t. I, Bologna 1888. Źródło to dostarcza także cennych informacji na temat trybu studiowania (o jakich porach prowadzone były wykłady, przez ilu profesorów itd.). 
można znaleźć w wydanych przez Celestino Pianę bolońskich aktach notarialnych ${ }^{29}$. Więcej informacji mogłaby dostarczyć kompleksowa kwerenda w archiwach miejskich, która dla XV w. nie została jeszcze przeprowadzona ${ }^{30}$. Stanisław Sroka zwrócił ostatnio uwagę na jeszcze jedno źródło, jakim jest diariusz bolońskiego plebana przy kościele św. Marii Magdaleny, Gasparego Codibò ${ }^{31}$. Wzmianki na temat pobytów (rzadziej studiów) Polaków w Bolonii można znaleźć w źródłach papieskich ${ }^{32}$. Wzmianki o tym, że dany kanonik czy prałat otrzymał pozwolenie i/lub stypendium na studia we Włoszech (najczęściej bez sprecyzowania ośrodka) lub w ogóle studia zagraniczne, albo o tym, że aktualnie studiuje we Włoszech (czasem z doprecyzowaniem, że w Bolonii) znajdują się w aktach polskich kapituł. Często jednak nie wynika z nich, czy osoba tam wymieniona wyjechała potem do Bolonii ${ }^{33}$. Dodatkowych informacji o bolońskich studiach prawniczych dostarczają niekiedy rękopisy proweniencji bolońskiej i zamieszczone w rękopisach noty odnośnie do studiów.

\section{TRYB STUDIÓW PRAWNICZYCH W BOLONII}

Rok akademicki dla studentów prawa w Bolonii zaczynał się 10 października albo dzień później i kończył z reguły pod koniec sierpnia ${ }^{34}$. Przeznaczone dla studentów prawa kanonicznego wykłady z Dekretałów, Liber Sextus i Liber Clementinarum odbywały się rano (de mane) i po południu (de sero). Dekret wykładany był w godzinach przedpołudniowych (de mane in tertiis) ${ }^{35}$. Studenci prawa cywilnego słuchali prowadzonych przez profesorów bolońskich wykładów Kodeksu i Infortiatum ${ }^{36}$.

${ }^{29} \mathrm{~W}$ przypadku niektórych nie wiadomo, czy studiowali prawo w Bolonii, np. Paweł z Polski wymieniony jako rector ecclesiae S. Ioannis Baptistae de Altedo Bonon. dioc. (C. P i a n a, Nuovi documenti sull'Università di Bologna e sul Collegio di Spagna, t. I-II, Bologna 1976, tu t. I, s. 747, nr 1807).

${ }^{30}$ S. A. S r o k a, Wykaz, s. 137; G. T a m b a, Chartularium, s. 171-180.

31 Diario bolognese di Mo Gaspare Codibó dal 1471 al 1504, con note e cronotassi dei priori e cappellani di Santa Maria Maddalena in Bologna, wyd. A. Macchiavelli, Bologna 1915 (Biblioteca de „L'Archiginnasio”, ser. II, nr 9); S. A. S r o k a, Polacy w Bolonii, s. 665-676. Za udostępnienie mi tego tekstu jestem bardzo wdzięczna profesorowi Stanisławowi Sroce.

32 Wydane w BP i Repertorium Germanicum. W Repertorium Germanicum można znaleźć informacje o święceniach przyjmowanych przez Polaków w Bolonii w czasie, gdy przebywała tam Kuria Rzymska, nie wiadomo jednak, czy przy okazji odbyli oni studia prawnicze na uniwersytecie bolońskim, np. Andreas Martini de Greverino [?] z diecezji gnieźnieńskiej [?] 2 VI 1436 r. uzyskał w Bolonii święcenia subdiakonatu (Repertorium Germanicum, t. V, wyd. H. Diener, Tübingen 2004, nr 281). Według dr. hab. Marka Daniela Kowalskiego nazwę tę można odczytać także jako Czreuerino [lub Czreuermo?] Gnesnenen. dioc. Nie udało mi się zidentyfikować tej miejscowości i osoby.

33 Acta capitulorum nec non iudiciorum ecclesiasticorum selecta, wyd. B. Ulanowski, t. I, Kraków 1894, nr 42, 84, 141, 161, 180, 327, 355, 432, 493, 536, 587, 592, 1143, 1159, 1162, 1736, 1741, 1746, 1764.

${ }^{34}$ A. S o r b e 11 i, Storia della Università di Bologna, t. I, Bologna 1940, s. 214.

35 Statuti, s. 104; U. D a 11 a ri, I rotuli.

${ }^{36}$ Księgi te wchodziły w skład kompilacji prawa rzymskiego podjętej na polecenie cesarza Justyniana w VI w. Ostateczny kształt i podział justyniańskiego Corpus iuris civilis był dziełem bolońskich glosatorów, którzy dzielili go na Digesta - złożony z 50 ksiąg zbiór cytatów słynnych prawników, uznawany za prawo. Kodeks to zbiór konstytucji wydawanych przez 
Księgi te wykładane były przez kilku profesorów rano (de mane) i po południu (de sero), a w kolejnym roku kilku profesorów wykładało Digestum vetus i Digestum novum rano i wieczorem. System wykładów prowadzony był tak, że umożliwiał wysłuchanie w ciągu dwóch lat całego Kodeksu i Digestum, gdyż w jednym roku obie części Kodeksu albo Digestum vetus i Digestum novum wykładane były w Bolonii rano (de mane) i po południu (de sero). Co roku wykładano też Institutiones, Libri authenticorum i Libri feudorum ${ }^{37}$. Pozwalało to na szybsze odbycie kursu z prawa cywilnego niż w Padwie ${ }^{38}$. Dla studentów organizowane były także repetitiones - szczegółowe objaśnianie tekstu, który był przedmiotem wykładu. Prowadzili je profesorowie albo częściej studenci ostatnich lat. Po karnawale studenci mogli uczestniczyć w dysputach prowadzonych przez profesorów ${ }^{39}$.

Studenci prawa w Bolonii mogli uzyskać dwa stopnie naukowe - licencjata i doktora (w Bolonii nie nadawano, tak jak na niektórych uniwersytetach, stopnia bakałarza dekretów). Aby uzyskać stopień licencjata, kandydat musiał zdać egzamin prywatny (privatum examen) przed komisją egzaminacyjną złożoną z członków kolegium doktorów.

Zgodnie ze statutami uniwersytetu prawników z 1432 r. student, aby przystąpić do egzaminu prywatnego z prawa kanonicznego, powinien studiować przez sześć lat i poprowadzić wykłady lub repetitiones. Jeśli jednak studiował jeszcze prawo cywilne przez pięć lat lub dłużej i chciał uzyskać doktorat z prawa kanonicznego, wystarczało studium prawa kanonicznego przez cztery lata, przy czym przez dwa z nich powinien studiować Dekretały, przez rok Dekret i przez rok słuchać innych wykładów bądź samemu wykładać jedną z pięciu ksiąg Dekretałów lub jedną causa z Dekretu, bądź też prowadzić repetitiones ${ }^{40}$. Kandydat do egzaminu z prawa cywilnego powinien uczęszczać na wykłady przez lat osiem lub siedem, o ile przez rok sam prowadził wykłady lub repetitiones. Jeśli oprócz tego studiował przez trzy lata prawo kanoniczne, cywilne mógł studiować o dwa lata krócej ${ }^{41}$. W praktyce jednak nieraz studenci nie uczestniczyli w wykładach, a do egzaminów przygotowywali się na podstawie komentarzy (recollectae) ${ }^{42}$. Aby móc prowadzić wykład, potrzebny do uzyskania stopnia z prawa, student musiał być wcześniej immatrykulowany, studiować przez cztery lata na kierunku, z którego chciał uzyskać stopień, i przynajmniej miesiąc wcześniej uczestniczyć $\mathrm{w}$ dysputach publicznych. W przypadku studiowania

cesarzy, Instytucje - podręcznik prawa rzymskiego, Nowele - zbiór rozporządzeń wydanych przez Justyniana po ogłoszeniu kodyfikacji. Średniowieczni prawnicy dzieli Digesta na trzy części: Digestum vetus (ks. 1-24,2), Infortiatum (ks. 25-38) i Digestum novum (ks. 39-50). Nowele od XI w. były znane pod nazwą Libri authenticorum (Authenticum). Do Corpus iuris civilis dołączono w średniowieczu zbiór longobardzkiego prawa lennego (Libri feudorum). Zob. P. Gre ndler, The Universities of the Italian Renaissance, Baltimore-London 2002, s. 435; M. A s c he ri, I diritti del Medioevo italiano. Secoli XI-XV, Roma 2000, s. 29-52.

${ }^{37}$ Por. U. D a 11 a ri, I rotuli.

${ }^{38}$ A. B e 11 o n i, Professori giuristi a Padova nel secolo XV. Profili bio-bibliografici, Frankfurt am Main 1986, s. 66; P. G r e nd l e r, The Universities, s. 453.

39 A. S o r b e 11 i, Storia, s. 214.

40 Statuti, S. 113.

${ }^{41}$ Tamże; A. S o r b e 11 i, Introduzione, s. XXXIV.

${ }^{42}$ A. B e 11 o n i, L'insegnamento giuridico, s. 145. 
obojga praw powinien odbyć cztery lata studiów na jednym kierunku i rok na drugim lub trzy lata studiów na jednym, a dwa na drugim ${ }^{43}$.

Egzamin prywatny w Bolonii odbywał się w zakrystii katedry św. Piotra i, jak wskazuje nazwa, nie był dostępny dla szerokiego grona publiczności - obecni byli tylko doktorzy kolegium, rektorzy uniwersytetu i personel obsługujący egzamin. Egzamin publiczny (conventus publicus, doctoratus), w wyniku którego nadawany był stopień doktora, odbywał się z reguły we wnętrzu katedry. Wiedza kandydata sprawdzana była w czasie egzaminu prywatnego, egzamin publiczny natomiast był uroczystą ceremonią kończącą się przekazaniem insygniów doktorskich. Uczestniczyła w niej cała społeczność uniwersytecka, przyjaciele oraz członkowie rodziny ${ }^{44}$. Wydatki związane z egzaminem publicznym obejmowały wystawne uczty, podarunki i datki pieniężne dla członków kolegium doktorskiego, a także woźnych (bedelli). Ich wysokość regulowały statuty. Kandydat na doktora musiał wręczyć 3 liry w monecie bolońskiej uniwersytetowi (debeat dare universitati tres libras Bononienses), każdemu z promotorów po 10 lub 12 dukatów albo tyleż łokci sukna o wartości dukata za łokieć, pozostałym doktorom obecnym na egzaminie zaś wpłacić nie więcej niż 3 liry w monecie bolońskiej. W przypadku egzaminu publicznego musiał wpłacić bedelowi (woźnemu) uniwersyteckiemu 4 dukaty (lub dać szaty), notariuszowi - 10 dukatów, bedelowi kolegium doktorów -2 dukaty ${ }^{45}$. Według wyliczeń Antoniego Pini ceremonia taka mogła kosztować nawet tyle samo, co pobyt w mieście uniwersyteckim przez 4-5 lat ${ }^{46}$. Studia w Bolonii, według Karola Górskiego, mogły kosztować dwa razy tyle, co w Niemczech ${ }^{47}$. Duży odstęp czasu między egzaminem prywatnym a publicznym wynikał więc najczęściej z konieczności zebrania środków na tę ostatnią uroczystość. Kolegium często wymagało od licencjata złożenia przysięgi, że przystąpi do egzaminu publicznego w określonym czasie. Musiał on też złożyć zastaw, najczęściej za pośrednictwem jednego z kupców bolońskich ${ }^{48}$.

\section{POLSCY DOKTORZY W BOLONII}

W pierwszej dekadzie XV w. doktorat z prawa kanonicznego w Bolonii uzyskał tylko jeden Polak, Był to Jakub z Polski, który 3 I 1401 zdał egzamin prywatny,

${ }^{43}$ Statuti, s. 188-189: Ad petitionem dictarum lecturarum de cetero nullus scolaris admittatur, nisi ipse fuerit matriculatus ad minus per mensem ante diem in qua fieri debet distributio lecturarum illius anni; item ad minus per mensem ante disputaverit publice aut repetierit, ut dicemus infra, ac etiam studuerit ad minus per quatuor annos in illa facultate in qua petere vellet lecturam, aut studuerit in una earum facultatum per quatuor annos, et in altera per unum, aut per tres in una et per duos in altera. Hi enim, qui mixtim studuerint, admittantur ad petitionem lecturarum in qua optaverint facultate.

${ }^{44}$ A. S o r b e 11 i, Introduzione, w: LC, 1421-1450, s. LI-LXI; A. L. Tro m b e t t i- B u d r i e s i, L'esame di laurea, s. 157-163.

${ }^{45}$ Statuti, s. 117-118.

${ }^{46}$ A. P i n i, Scolari ricchi e scolari poveri tra medioevo ed età moderna, w: Studio, università e città nel medioevo bolognese, Bologna 2005, s. 108.

${ }^{47}$ K. Gó r s k i, Studenci z Prus w Bolonii w XIV i XV wieku, Komunikaty Mazursko-Warmińskie 1989, nr 1-4, s. 4.

${ }^{48}$ A. L. Trombett i-B udries i, L'esame di laurea, s. 164. 
a 26 I 1401 r. przystąpił do egzaminu publicznego ${ }^{49}$. Nie został on jednak zidentyfikowany w sposób pewny ${ }^{50}$, nie wiadomo więc, $\mathrm{w}$ jakim wieku i na jakim etapie kariery rozpoczął studia w Bolonii. Można przypuszczać, że odbył pełne studia prawnicze, gdyż nie ma informacji o udzieleniu mu dyspensy od obowiązku studiowania przez określone statutami lata. Musiał pochodzić z majętnej rodziny, gdyż do egzaminu publicznego przystąpił w tym samym miesiącu, co do egzaminu prywatnego.

W drugiej dekadzie XV w. doktoraty zdobyło w Bolonii dwóch Polaków. Pierwszy z nich to Piotr z Krakowa, który 2 IX 1413 r. przystąpił do egzaminu prywatnego z prawa kanonicznego ${ }^{51}$. Został on zidentyfikowany przez Jana Fijałka jako pochodzący z rodziny mieszczańskiej Piotr Wolfram (zm. 1428), który w 1402 r. był plebanem kościoła w Prandocinie w diecezji krakowskiej, później pełnił funkcję pisarza miejskiego we Lwowie i altarysty w tamtejszym kościele Matki Boskiej Śnieżnej ${ }^{52}$. W momencie rozpoczęcia studiów prawniczych miał już za sobą doświadczenie jako dyplomata - w 1407 r. jeździł do Kurii Rzymskiej jako przedstawiciel miasta Lwowa i arcybiskupa halickiego Jakuba. W 1408 r. zaczął studia prawnicze w Pradze, ale w następnym roku, w związku z dekretem kutnohorskim i towarzyszącymi mu wydarzeniami, opuścił to miasto, podobnie jak inni studenci niemieccy i polscy. W tym samym roku Piotr został wysłany przez króla do papieża Aleksandra V, przebywającego wtedy w Bolonii. Do Polski Wolfram wrócił przed 2 XII $1410 \mathrm{r}$. Nie można wykluczyć, że w czasie pobytu w Kurii, rezydującej wtedy w Bolonii, Piotr podjął studia prawnicze. Poświadczony jest następnie na studiach prawniczych w Padwie, gdzie 28 VIII 1411 r. jako pleban w Prandocinie był świadkiem na egzaminie prywatnym z prawa kanonicznego ${ }^{53}$, a między $11 \mathrm{X}$ a $30 \mathrm{XII}$ tr. pełnił funkcję wicerektora ultramontanów. W Padwie był jeszcze 23 XII 1411, a 24 VIII 1412 r. brał udział w zjeździe w Nowym Korczynie. Nie wiadomo, kiedy ponownie udał się na studia, tym razem do Bolonii, gdzie 2 IX 1413 r. uzyskał stopień licencjata dekretów. W Liber secretus został określony tylko jako Piotr z Krakowa, nie wiadomo, czy występował w Bolonii jako pleban w Prandocinie. Można podejrzewać, że nie odbył pełnych studiów prawniczych, chociaż w Liber secretus nie ma informacji o udzieleniu mu dyspensy od wymaganych lat studiów. W każdym razie w Bolonii studiował dość krótko. Po egzaminie prywatnym (licencjat) nie przystąpił do egzaminu

49 ASB, Studio 126, k. 27r; J. F i j a ł e k, Polonia, s. 18-19 (venerabilis et nobilis vir dominus Jacobus de Polonia).

${ }^{50}$ J. F i j a ł e k, Polonia, s. 18-19, sugeruje, że mógł to być Jakub Kmita z Wiśnicza.

${ }^{51}$ ASB, Studio 126, k. 41v; J. F i j a ł e k, Polonia, s. 38 (dominus Petrus de Cracovia).

52 J. F i j a ł e k, Polonia, s. 37-38; M. Z w i e r c a n, Piotr z Krakowa, w: PSB XXVI (1981), s. 404; K. O ż ó g, Piotr Wolfram, w: Profesorowie Wydziału Prawa Uniwersytetu Jagiellońskiego, t. I, Kraków 2015, s. 337-339; В. П е т р и ш а к, Кар'єри публічних нотаріїв у Львові XV-XVI ст, Średniowiecze Polskie i Powszechne 3 (7), 2011, s. 175. M. D. K o w a ls k i, Dlaczego warto było zostać kolektorem? Kariery papieskich kolektorów generalnych w Polsce XV wieku, Roczniki Historyczne 80, 2014, s. 135-138.

${ }^{53}$ Egzamin zdawał Petrus de Helpurgh (J. F i j a ł e k, Polonia, s. 37), najprawdopodobniej Piotr von Heldburg (zm. 1441), licencjat prawa kanonicznego, kapelan króla Zygmunta, który w 1422 r. skierował w jego sprawie pismo polecające do papieża Marcina V - A. We n d e h o r s t, Das Bistum von Eichstätt, t. I, Berlin - New York 2006 (Germania Sacra, Neue Folge 45), s. 203. 
publicznego (doktorat), zapewne ze względów finansowych. Studia i stopień licencjata bolońskiego musiały być potrzebne wywodzącemu się z mieszczaństwa Wolframowi do kariery (później zdobył kolejne beneficja, został też kolektorem świętopietrza). W jego przypadku możemy wszakże mówić o przynajmniej częściowo bolońskiej (obok praskiej) formacji prawniczej, która służyła mu potem w karierze uniwersyteckiej. W 1415 r. został profesorem Wydziału Prawa Uniwersytetu Krakowskiego.

Dwa lata po Piotrze Wolframie stopień naukowy z prawa kanonicznego uzyskał w Bolonii Mirosław z Brudzewa (zm. 1427), syn Kiełcza ${ }^{54}$. Ten przedstawiciel rodu Nałęczów rozpoczął studia w Bolonii, będąc już w dojrzałym wieku i w trakcie zaawansowanej kariery kościelnej: już w 1394 r. był plebanem we Wrześni i altarystą gnieźnieńskim, zanim uzyskał doktorat w Bolonii, został także kanonikiem poznańskim (przed 13 XI 1403). Miał też doświadczenia związane z działalnością w Kurii Rzymskiej. Kontynuował ją zresztą po zakończeniu studiów bolońskich. W 1392 r. zapisał się na uniwersytet prawniczy w Pradze. Jako rektor ultramontanów w Bolonii przystąpił 23 III 1415 r. do egzaminu prywatnego, a 30 IV tr. do egzaminu publicznego z prawa kanonicznego ${ }^{55}$. Nie wiadomo, ile czasu studiował prawo w Bolonii, można sądzić, że dopełnił obowiązku studiowania przez wymagane statutami lata, tym bardziej że studiował wcześniej w Pradze. Bolońskie studia prawnicze i zdobyty tam stopień doktora dekretów z pewnością ułatwiły mu dalszą karierę kurialną. Przed 1408 był kapelanem kardynała Oddona Colonny, późniejszego papieża Marcina V, w 1418 występował jako prokurator kapituły i arcybiskupa gnieźnieńskiego w Kurii, w 1420 został określony jako familiaris papieski, w 1421 był szambelanem papieskim, przed 1424 datariuszem suplik papieskich i pisarzem Penitencjarii, wreszcie w 1426 r. otrzymał od papieża prowizję na biskupstwo poznańskie. Posiadał bibliotekę prawniczą i teologiczną, którą zapisał swojemu bratankowi Niemierzy, nie wiadomo jednak, jakie dzieła wchodziły w jej skład i w jakim stopniu odzwierciedlały jego studia prawnicze ${ }^{56}$.

Inny od wyżej opisanego model studiowania reprezentują czynni w tym samym czasie Wojciech Jastrzębiec (zm. 1431) i jego brat Filip z Borysławic (zm. po 1447),

${ }^{54}$ M. C z y ża k, Kapituła katedralna w Gnieźnie w świetle metryki z lat 1408-1448, Poznań 2003, s. 375-376; J. F i j a ł e k, Polonia, s. 45-48, J. N o w a c k i, Brudzewski Mirosław, w: PSB III (1937), s. 9.

55 LC 1378-1420, k. 43r: Eodem millesimo CCCCXV die XIII Martii dominus Miroslaus de Polonia rector dominorum ultramontanorum fuit presentatus per dominum Chilinum de Argile iuris utriusque doctorem et me Bernardinum de Zambechariis priorem dicti collegii. Et omnes cetule fuerunt aprobatorie. Et tunc temporis prefatus dominus Jeremias de Angellelis tenebat locum meum. Qui iuravit etc. --Die trigesimo Aprilis dominus Mrcoslaus de Polonia rector recepit publicam in Sancto Petro et dominus Bernardinus dedit insignia doctoratus et d. Chilinus fecit sermonem archidiaconi et $d$. Jeremias tenuit locum meum.

${ }^{56}$ J. N o w a c k i, Brudzewski, s. 10; zob. Kodeks dyplomatyczny Wielkopolski, t. IX, wyd. A. Gąsiorowski, T. Jasiński, Warszawa-Poznań 1990, nr 1120. M. C z y ż a k, Legat książkowy archidiakona Mikołaja Kickiego dla katedry gnieźnieńskiej. Przyczynek do kultury intelektualnej duchowieństwa wielkopolskiego w pierwszej połowie XV wieku, Ecclesia. Studia z Dziejów Wielkopolski 5, 2010, s. 10, przypuszcza, że do Mirosława mógł należeć przywieziony z Konstancji rękopis z traktatami prawników włoskich Fryderyka de Senis, Jana Calderiniego, Baldiego de Ubaldis i Dominika z San Geminiano; na k. 1 kodeksu znajduje się herb Nałęcz. 
synowie podkomorzego łęczyckiego Mikołaja z Borysławic, którzy swoje kilkuletnie studia prawnicze $\mathrm{w}$ Bolonii rozpoczęli w stosunkowo młodym wieku ${ }^{57}$. Wywodzili się z rodu awansującego dzięki stryjowi wspomnianych braci, Wojciechowi, kanclerzowi królowej Jadwigi, biskupowi poznańskiemu, krakowskiemu i w końcu arcybiskupowi gnieźnieńskiemu ${ }^{58}$. Nieco więcej informacji mamy na temat osoby i studiów pierwszego z braci, Wojciecha ${ }^{59}$. Wcześnie zdobył beneficja. Już w $1410 \mathrm{r}$. określany był jako kanonik łęczycki i w tym samym roku otrzymał prowizję papieską na kanonię wiślicką, krakowską i gnieźnieńską, w 1412 r. - na kanonię poznańską, a w $1414 \mathrm{r}$. został prepozytem poznańskim. Wiadomo, że studiował najpierw w Wiedniu (po 1409, a przed 1417 r.). Pod koniec 1417 r. przybył do Padwy, gdzie został wicerektorem (z tym tytułem występował 14 X 1418 i 5 X 1420) ${ }^{60}$. Do Padwy przyjechał na krótko jeszcze raz w styczniu $1422 \mathrm{r}^{6}{ }^{61}$, być może z Bolonii, gdzie $27 \mathrm{~V}$ tr. przystąpił do egzaminu prywatnego z prawa kanonicznego. Został jednomyślnie promowany, kolegium doktorskie uhonorowało jego przynależność do możnego rodu - po zakończonym egzaminie odprowadzono go do domu ${ }^{62}$. Nie wiadomo, czy Filip studiował razem z Wojciechem w Wiedniu, ale można sądzić, że przyjechał razem z bratem na studia do Bolonii, na co wskazywałby bardzo zbliżony czas przystępowania do egzaminu prywatnego i wspólny egzamin publiczny. Filip do egzaminu prywatnego przystąpił trzy dni później niż brat, $30 \mathrm{~V} 1422 \mathrm{r}^{63}$ Wkrótce po uzyskaniu licencjatu musieli wrócić do Polski, gdyż 18 X 1422 r. wystąpili już w Krakowie jako świadkowie na dokumencie stryja, biskupa krakowskiego ${ }^{64}$.

57 Zdaniem badaczy Wojciech Jastrzębiec mógł się urodzić ok. 1389-1396, skoro w 1414 r. otrzymał prepozyturę poznańską z dyspensą od przeszkody wieku; należy sądzić, że młodszy był Filip, który dopiero w 1427 r. został określony w źródłach jako prezbiter (P. D e m b i ń s k i, Poznańska kapituła katedralna schyłku wieków średnich. Studium prozopograficzne 1428-1500, Poznań 2012, s. 380, 711).

${ }^{58}$ G. L i c h o ń c z a k - N u re k, Wojciech herbu Jastrzębiec, arcybiskup i mąż stanu (ok. 1362-1436), Kraków 1996; t a ż, Wojciech Jastrzębiec i jego rodzina, w: Cracovia Polonia - Europa. Studia z dziejów średniowiecza ofiarowane Jerzemu Wyrozumskiemu W sześćdziesiątą piątą rocznicę urodzin i czterdziestolecie pracy naukowej, Kraków 1995, s. 329-343. B. C z w o j d ra k, Jastrzębce w ziemi krakowskiej i sandomierskiej do połowy XV wieku, Kraków 2007.

59 J. F i j a łe k, Polonia, s. 64; P. D e m b i ń s ki, Poznańska kapituła, s. 711-712; G. L i c h oń c z a k-N u re k, Wojciech Jastrzębiec i jego rodzina, s. 334; K. O ż ó g, Wojciech Jastrzębiec, w: Profesorowie Wydziału Prawa (jak w przyp. 52), s. 436-437.

${ }^{60}$ D. G a 11 o, Lauree inedite in diritto civile e canonico presso lo Studio di Padova (14191422, 1423, 1424, 1428), Quaderni per la storia dell'Univerità di Padova 20, 1987, s. 22-23.

${ }^{61}$ Świadczy o tym nota celna na k. Ir jego rękopisu zawierającego Apparatus super Decreto Guida da Baysio (Biblioteka Jagiellońska, rkps 371): Dominus Albertus conduxit in Paduam 28 Ianuarii 1422; zob. L. G a r g a n, L'enigmatico „,conduxit”. Libri e dogana a Padova fra Tre e Quattrocento, Quaderni per la Storia dell'Università di Padova 16, 1983, s. 23-24; Catalogus codicum manuscriptorum medii aevii Latinorum qui in Bibliotheca Jagellonica Cracoviae asservantur, t. II, red. M. Kowalczyk, Wrocław 1982, s. 125-126.

${ }^{62}$ ASB, Studio 126, k. 50r; J. F i j a ł e k, Polonia, s. 63 (venerabilis ac egregius vir d. Albertus Nicolai prepositus Poznaniensis).

${ }^{63}$ J. Fij a łe k, Polonia, s. 66 (ze znakiem zapytania sugerował tu Filipa z Fałkowa);

P. D e m b iń s k i, Poznańska kapituła, s. 380.

${ }^{64}$ Codex diplomaticus Universitatis studii generalis Cracoviensis, t. I, Kraków 1870, nr 71. 
Dwuletni odstęp między egzaminem prywatnym a publicznym obu braci (10 IV 1424) może wskazywać na trudności z zebraniem środków na pokrycie kosztów egzaminu publicznego. Przystępując wspólnie do egzaminu publicznego, Wojciech i Filip z pewnością chcieli zmniejszyć owe koszty ${ }^{65}$. Możliwe, że stopień doktora stał się dla nich ważny, gdy ich stryj został arcybiskupem $(1423)^{66}$. Obydwaj zrobili kariery kościelne, gromadząc liczne beneficja (z tym że Filip, zapewne z racji wieku, nieco później - dopiero w 1424 r. uzyskał prowizję na kanonię wrocławską, gnieźnieńską i krakowską oraz altarię św. Wawrzyńca w Sandomierzu) ${ }^{67}$. Wojciech był w 1427 r. kandydatem na biskupstwo poznańskie. Dzięki studiom prawniczym Wojciech po powrocie został profesorem Uniwersytetu Krakowskiego, Filip natomiast pełnił w Kurii Rzymskiej funkcję pełnomocnika biskupa Zbigniewa Oleśnickiego (1425) i Andrzeja Myszki z Nieprześni (1427).

W podobnym czasie co Wojciech i Filip studiował w Bolonii także Adam z Będkowa $^{68}$ herbu Prus (zm. 1451), który 24 III 1423 r. zdał w Bolonii egzamin prywatny z prawa kanonicznego, a $27 \mathrm{~V}$ tr. odbył egzamin publiczny ${ }^{69}$. Podobnie jak Piotr Wolfram i Mirosław z Brudzewa studia prawnicze w Bolonii podjął w trakcie zaawansowanej już kariery. W 1400 r. był już notariuszem publicznym imperiali auctoritate. Posiadał potem liczne beneficja (m.in. kanonię gnieźnieńską od 1404, archiprezbiterat kościoła NMP w Krakowie od 1413, dziekanię kielecką od 1423 r.), co zostało nawet odnotowane przez notariusza bolońskiego rejestrującego jego egza$\min ^{70}$. Bywał już wcześniej we Włoszech i w Bolonii w czasie misji dyplomatycznych (w 1. 1409/1410 jako poseł Władysława Jagiełły do Aleksandra V przebywającego w Bolonii, 1411 i 1422-1423 w Kurii Rzymskiej jako prokurator kapituły gnieźnieńskiej). Wiadomo, że nie odbył pełnych studiów prawniczych, gdyż kolegium bolońskich doktorów prawa kanonicznego udzieliło mu dyspensy zezwalającej na

${ }^{65}$ ASB, Studio 126, k. 52v; J. F i j a ł e k, Polonia, s. 63 (reverendus et egregius vir d. Albertus Nicolai prepositus Poznaniensis et egregius vir dominus Filipus Nicolai de Polonie regno. Ambo dicto die fecerunt publicam suam seu conventum perhonorabilem valde).

${ }^{66} \mathrm{G}$. L i c h o ń c z a k - N u r e k, Wojciech herbu Jastrzębiec, s. 144.

${ }^{67}$ P. D e m biń ski, Poznańska kapituła, s. 380-381; M.D. K o w a 1 s k i, Proventus camerae apostolicae debiti. Opłaty duchowieństwa polskiego na rzecz papiestwa w latach 1417-1484, Kraków 2010, s. 110.

68 J. F i j a ł e k, Polonia, s. 70-73; P. D e m b iń s k i, Poznańska kapituła, s. 339; M. C z y ż a k, Kapituła, s. 311-312; M. Z d a n e k, Adam z Będkowa, w: Profesorowie Wydziału Prawa (jak w przyp. 52), s. 3; K. O ż ó g, Uczeni w monarchii Jadwigi Andegaweńskiej i Władysława Jagiełły (1384-1434), Kraków 2004, s. 54, 173.

${ }^{69}$ Egzamin prywatny (ASB, Studio 126, k. 50v; J. F i j a ł e k, Polonia, s. 71: dominus Adam Nicolai de Bathcovv de Polonia). Egzamin publiczny (ASB, Studio 126, k. 51r; J. F i j a ł e k, Polonia, s. 71: dominus Adam Nicolai de Polonia).

${ }^{70}$ ASB, Studio, Arcidiacono 1, k. 39v: Die vigesimo septimo Maii conventus domini Ade Nicolai de Banthcovv de Polonia de Polonia [!] in iure canonico, qui die XXVII mensis Maii proximi preteriti fuit presentatus domino archidiacono Bon. per dominos Bernardinum de Zambechariis et Johannem Andream de Caldarinis. Dominus Johannes de Guasconibus locumtenens dicti domini archidiaconi dedit sibi licentiam doctoratus. Dominus Johannes Andreas predictus suo nomine et nomine domini Bernardini dedit sibi insignia; przy imieniu Adama dopisano inną ręką na prawym marginesie: decanus Kyelcensis, a na lewym: archipresbiter Sancte Marie Cracoviensis et Gneznensis et Cracoviensis ecclesiarum canononicus. 
przystąpienie do egzaminu prywatnego, mimo że nie studiował prawa kanonicznego przez wymagane pięć lat. Doktorat uzyskał więc niejako przy okazji swojej misji dyplomatycznej. Studia prawnicze i pewną formację prawniczą musiał jednak zdobyć (choć w krótszym wymiarze, niż przewidywały statuty, i nie wiadomo, czy w Bolonii), gdyż po powrocie do kraju został przyjęty do grona profesorów prawa Uniwersytetu Krakowskiego. Zdobyte przez niego wykształcenie prawnicze zapewne zdecydowało o tym, że trafił do grona ekspertów, doktorów prawa kanonicznego, którzy wspólnie opracowali consilium dotyczące planów koronacji Witolda na króla Litwy.

Podobnie wyglądały bolońskie studia prawnicze Gotarda z Gurby (zm. 1432), kanonika warszawskiego (od 1412 r. i z tym tytułem odnotowanego przez notariusza bolońskiego) i oficjała warszawskiego (od 1420/1421) $)^{71}$. Do egzaminu prywatnego z prawa kanonicznego w Bolonii przystąpił on 21 VII $1424 \mathrm{r}^{72}$, a do egzaminu publicznego pięć dni później ${ }^{73}$. Formację z zakresu sztuk wyzwolonych zdobył w Pradze, gdzie w 1405 r. został dopuszczony do egzaminu na bakałarza ${ }^{74}$. Jego studia prawnicze w Bolonii musiały trwać krótko, gdyż uzyskał on zwolnienie z obowiązku wysłuchania wszystkich wymaganych statutami wykładów ${ }^{75}$.

Kolejni Polacy uzyskiwali doktoraty z prawa w Bolonii w latach czterdziestych XV w. Powszechną praktyką stało się wówczas korzystanie przez nich ze zwolnień z obowiązku wysłuchania przepisanych statutami wykładów i prowadzenia repetitiones, a także korzystanie $\mathrm{z}$ tańszej i szybszej procedury odbywania egzaminu publicznego w formie ,prywatnej” - zaraz po egzaminie prywatnym w zakrystii, a nie w nawie katedry. Uzyskiwanie doktoratu privatim pozwalało zaoszczędzić na kosztach uroczystości. Przypadki nadawania insygniów doktorskich w zakrystii ob paupertatem zdarzały się już w XIV w. ${ }^{76}$, choć nie była to wtedy rozpowszechniona praktyka i nie ma informacji o Polakach, którym by pozwolono skorzystać z tej możliwości. Promowany w ten sposób doktor miał być traktowany na równi z doktorami, którzy odbyli zwyczajowy egzamin publiczny ${ }^{77}$.

${ }^{71}$ Informacje na temat pochodzenia Gotarda i daty jego śmierci podane przez J. F i j a łk a, Polonia, s. 68, zostały sprostowane w nowszych pracach: A. R a d z i m i ń s k i, Prałaci i kanonicy kapituły katedralnej płockiej w XIV i I poł. XV w. Studium prozopograficzne, t. I-II, Toruń 1991-1993, tu t. I, s. 78; P. D e m b iń s k i, Poznańska kapituła, s. 384.

${ }^{72}$ ASB, Studio, Arcidiacono 1, k. 57v: Examen domini Gothardi de Mazovia canonici Warschoviensis in iure [skreślone: civili] canonico presentati domino Petro Aristoteli locumtenenti domini archidiaconi per dominos Antonium de Albergatis et Johannem Andream de Caldarinis, approbatus et licentiatus.

73 ASB, Studio 126, k. 53v; J. F i j a ł e k, Polonia, s. 68.

${ }^{74}$ Liber decanorum facultatis philosophicae Universitatis Pragensis ab anno Christi 1367 usque ad annum 1585, Pragae 1830-1832 (Monumenta Universitatis Carolo-Ferdinandeae Pragensis, t. I/1), s. 386; P. D e m b i ń s k i, Poznańska kapituła, s. 384.

${ }_{75}$ ASB, Studio 126, k. 53v; J. F i j a ł e k, Polonia, s. 68 (dominus Got[h]ardus de Polonia).

${ }^{76} \mathrm{~W} 1379 \mathrm{r}$. egzamin publiczny w zakrystii zaraz po egzaminie prywatnym odbył Antonio Sartori da Trento (A. L. Tr o m be t t i - B u dri e s i, L'esame di laurea, s. 164).

${ }_{77} \mathrm{~W} 1425$ r. kolegium doktorów prawa cywilnego podjęło postanowienie uznające doktoraty prywatne $\mathrm{w}$ zakrystii lub $\mathrm{w}$ innym miejscu, po ogłoszeniu przez archidiakona tego miejsca miejscem publicznym, ale w $1451 \mathrm{r}$. próbowało powstrzymać zbyt częste zdobywanie doktoratów ,prywatnych" i postanowiło, że żaden ze studentów nieposiadających obywatelstwa bolońskiego nie może odbyć doktoratu ,prywatnie” bez wcześniejszej zgody kolegium, 
W 1445 r. na 10 doktoratów z prawa cywilnego aż 9 miało miejsce w zakrystii, a tylko jeden w nawie ${ }^{78}$.

Pierwszym przedstawicielem tej grupy Polaków jest Mikołaj z Mirzyńca herbu Bończa (zm. 1475) ${ }^{79}$, który uzyskał w Bolonii licencjat prawa kanonicznego w 1443 r. Nie jest znana dokładna data jego przyjazdu do Bolonii. Nastąpiło to po uzyskaniu przez niego w 1438 r. stopnia magistra na Wydziale Sztuk Uniwersytetu Krakowskiego ${ }^{80}$. Należy sądzić, że w studiował prawo kanoniczne przez zgodny ze statutami czas (choć nie wiadomo, czy tylko w Bolonii czy też na innym jeszcze uniwersytecie), gdyż nie ma żadnej informacji o udzieleniu mu zwolnienia. W dniu 11 IX 1443 r. zdał z wyróżnieniem egzamin prywatny z prawa kanonicznego ${ }^{81}$. Następnie udał się na pewien czas do Rzymu ${ }^{82}$, a 27 II 1445 r. uzyskał w Bolonii licencjat prawa cywilnego, po wcześniejszym zwolnieniu z obowiązku studiowania przez określony statutami czas i prowadzenia repetitiones ${ }^{83}$. W dniu 5 IV 1446 r. zdobył w Bolonii doktorat dekretów ${ }^{84}$. Po powrocie do kraju wykorzystywał wiedzę prawniczą jako oficjał płocki (został nim między 11 VII 1446 a 22 VI 1447 r.). Zajmował się też biblioteką kapitulną płocką i występował jako rzecznik książąt mazowieckich w sprawie lenna płockiego na zjeździe w Łęczycy w 1462 r. Ze swych studiów przywiózł rękopisy prawnicze ${ }^{85}$.

Krócej, niż wymagały statuty, studiował w Bolonii prawo kanoniczne Zygmunt z Giżyc herbu Gozdawa (zm. 1456) ${ }^{86}$. Najpierw odbył studia na Wydziale Sztuk w Krakowie, gdzie immatrykulował się w 1427 r. W 1441 r. jako dziekan kruszwicki (objął to beneficjum po 20 VII 1429 r.) udał się na studia prawnicze do Bolonii (być może został wysłany tam przez brata, biskupa płockiego Pawła Giżyckiego), w czasie których uzyskał dziekanię płocką (1444) oraz został mianowany nuncjuszem

uzyskanej przez głosowanie (A. L. Tro m b ett i - B u dri e s i, L'esame di laurea, s. 186; A. S o r b e 11 i, Introduzione, w: LC 1421-1450, s. XLV).

${ }^{78}$ LC 1421-1450, s. 218-236.

79 S. M. S z a c h e r s k a, Mikołaj z Mirzyńca, w: PSB XXI (1976), s. 126; A. R a d z i m ińs k i, Prałaci i kanonicy, t. II, s. 114.

${ }^{80}$ NKP nr 37/4.

${ }^{81}$ ASB, Studio 126, k. 108v; J. F i j a ł e k, Polonia, s. 88 (dominus Nicolaus Sdzeslay de Polonia canonicus ecclesie Poltaviensis, artium doctor).

82 Świadczy o tym jego nota w zaginionym rękopisie prawniczym MS 18 (50), który przed II wojną światową znajdował się w Bibliotece Kapitulnej w Płocku: Anno Domini 1444 XIX die Decembris, hora XX scriptum Rome per me N. de Mirzinecz Ploc. diocesis arcium liberalium magistrum, licentiatum in decretis, studentem iuris civilis, pontificatus s(anctissimi) in Christo patris et domini, domini Eugenii pape quarti anno ipsius XIII, indictione septima (A. Vetulani, Średniowieczne rękopisy płockiej biblioteki katedralnej, Roczniki Biblioteczne 7, 1963, z. 3-4, s. 393-394).

${ }^{83}$ LC 1421-1450, s. 220; J. F i j ał e k, Polonia, s. 88 (dominus Nicholaus de Polonia).

${ }^{84}$ J. F i j a ł e k, Polonia, s. 88.

${ }^{85} \mathrm{O}$ zainteresowaniu prawem świadczy pozostawiony przez niego dla biblioteki kapitulnej płockiej rękopis z De ordine iudiciorum Roffreda da Benevento, do którego własnoręcznie sporządził indeks (A. Ve tu la ni, Średniowieczne rękopisy, s. 37).

${ }^{86}$ T. Sło wi k o w s k i, Giżycki Zygmunt, w: PSB VIII (1959-1960), s. 28; J. Fi j a ł e k, Polonia, s. 91; A. R a d z i m iń s k i, Prałaci i kanonicy, t. I, s. 155; M.D. K ow a ls k i, Proventus, s. 195. 
apostolskim i kolektorem papieskim na Czechy i na Polskę (16 XII 1444). W dniu 22 II 1445 r., po uzyskaniu zwolnienia z obowiązku studiowania przez pełne pięć lat, prowadzenia repetitiones i słuchania wykładów Dekretu, przystąpił do egzaminu prywatnego ${ }^{87}$. Jak należy przypuszczać, brakowało mu środków na uroczysty egzamin publiczny, gdyż insygnia doktorskie otrzymał ponad rok później, 5 IV 1446 r., i to „prywatnie” w zakrystii ${ }^{88}$. Wkrótce po uzyskaniu stopnia doktora dekretów został prepozytem płockim (11 VII 1446). Współpracował ze swoim bratem biskupem (złożył w jego imieniu obediencję Mikołajowi V).

Kolejnym Polakiem studiującym w Bolonii w latach czterdziestych był Mikołaj (Niklin) Chebda z Niewiesza herbu Pomian (zm. 1455), który doktorat dekretów zdobył 5 IV 1448 r. ${ }^{89}$ Prawdopodobnie identyfikować go należy z Mikołajem z Polski, który 22 II 1445 r. przystąpił do egzaminu prywatnego z prawa cywilnego ${ }^{90}$. Nie wiadomo, gdzie studiował sztuki wyzwolone. Studia prawnicze podjął w dojrzałym wieku, dysponując już licznymi beneficjami - kanonią kruszwicką i dziekanią kielecką (od 1423), kanonią włocławską (od 1426), prepozyturą kolegiaty św. Michała na Wawelu (od 1425), archidiakonią płocką (1426-1434/1435), prepozyturą kruszwicką (od 1428), kanonią poznańską i kanonią gnieźnieńską (od 1444). Można w przybliżeniu oszacować czas jego studiów prawniczych w Bolonii. W dniu 16 VIII $1438 \mathrm{r}$. otrzymał zgodę biskupa i kapituły włocławskiej na studia we Włoszech (z wyjątkiem Rzymu i Ferrary), a 24 VIII 1446 r. kapituła poznańska i gnieźnieńska udzieliły mu stypendium na kontynuację studiów w Bolonii, a także jako wynagrodzenie za usługi, które miał wyświadczyć kapitule poznańskiej w Kurii Rzymskiej. W roku akademickim 1447-1448 pełnił funkcję rektora ultramontanów i citramontanów i wykładał Dekret oraz Digestum vetus ${ }^{91}$. Do egzaminu z prawa cywilnego przystąpił po otrzymaniu wcześniejszej dyspensy od obowiązku studiowania i prowadzenia repetitiones zgodnie ze statutami (wykłady z prawa cywilnego prowadził dopiero po uzyskaniu licencjatu). Relacja Liber secretus z przebiegu jego egzaminu wskazuje, że był odpowiednio przygotowany, gdyż został aprobowany przez wszystkich członków kolegium doktorskiego ${ }^{92}$. W przypadku egzaminu z prawa kanonicznego, który zdał 5 IV 1448 r., nie ma żadnej wzmianki o udzieleniu mu dyspensy od lat studiów. W tym wypadku wcześniejsze studiowanie prawa cywilnego pozwalało mu skrócić

${ }^{87}$ ASB, Studio 126, k. 79v; J. F i j a ł e k, Polonia, s. 91-92 (d. Sigismondus de Giszeze decanus ecclesie Poloniensis Regni Polonie).

${ }^{88}$ ASB, Studio 126, k. 81r; J. F i j a ł e k, Polonia, s. 91 (dominus Sismondus Vincentii de Ghyscg decanus ecclesie Procensis de Polonia).

89 ASB, Studio 126, k. 83v; J. Fij ał e k, Polonia, s. 96 (dominus Nicholaus Chbde de Polonia rector ultramontanorum et etiam citramontantanorum).

${ }^{90}$ LC 1421-1450, s. 220: Die XXV eiusdem [II 1445] fuit dispensatum cum domino Nicholao de Polonia pro eo, quia non studuerat et repecierat secundum tenorem constitutionis et predictis non obstantibus posset subire privatum examen in iure civili. Die XXII eiusdem dominus Nicholaus de Polonia predictus fuit subiectus privato examini iuris civilis. J. F i j a ł e k, Polonia, s. 94, nie wspominał o stopniu Mikołaja Chebdy z prawa cywilnego, ale P. D e m b iń s k i, Poznańska kapituła, s. 576, przypuszczał, że miał również doktorat z prawa rzymskiego.

${ }^{91}$ U. D a 11 a r i, I rotuli, s. 22; J. F i j a ł e k, Polonia, s. 95 (d. Nicolaus Chebe de Nieviesch dignissimus rector dominorum scolarium ultramontanorum).

${ }_{92}^{2}$ LC 1421-1450, s. 220: fuitque aprobatus ab omnibus, nemine discorde et merito. 
czas nauki prawa kanonicznego. Znów został jednomyślnie promowany przez całe kolegium doktorskie. Bezpośrednio po egzaminie prywatnym otrzymał insygnia doktorskie (uzyskał wcześniej dyspensę na przystąpienie do egzaminu publicznego bez towarzyszących mu uroczystości) ${ }^{93}$. W dniu 4 VII 1448 r. kapituła poznańska przyznała mu 10 grzywien jako nagrodę za doktorat, podnosząc w uzasadnieniu (co może być zresztą zwrotem retorycznym), że zdobył doktorat bardziej na chwałę Korony Polskiej i kapituł, które reprezentował, niż dla pożytku własnego ${ }^{94}$. Bolońskie studia prawnicze i stopień doktora miały go dobrze przygotować do załatwiania interesów polskich w Kurii Rzymskiej, gdzie przebywał w 1448 r. W Rzymie zaczął karierę kurialną - w 1450 r. otrzymał tytuł pokojowca i szambelana papieskiego. Po śmierci Wincentego Kota z Dębna był kandydatem na arcybiskupa gnieźnieńskiego, ale musiał się wycofać, gdyż zyskał tylko dwa głosy poparcia ${ }^{95}$.

Jednocześnie z Mikołajem Chebdą studiował w Bolonii i zdobył stopień z prawa Jan z Pniowa herbu Abdank (zm. 1476) ${ }^{96}$. Zanim udał się do Bolonii, studiował już sztuki wyzwolone na Uniwersytecie Krakowskim ${ }^{97}$. Jako notariusz publiczny (1431-1435) zdobył doświadczenie w pracy w konsystorzu krakowskim i w kancelarii biskupa Zbigniewa Oleśnickiego. Zasiadał już w kilku kapitułach: był kanonikiem krakowskim (od 1437), archidiakonem zawichojskim (od 1438), kanonikiem sandomierskim i włocławskim (od 1440), a w 1. 1440-1449 pełnił również funkcję oficjała krakowskiego. Wątpliwości budzi czas trwania jego studiów prawniczych w Bolonii. W 1440 r. otrzymał zgodę kapituły włocławskiej na odbycie studiów prawniczych $^{98}$. Nie ma dowodu, że podjął je wtedy w Bolonii. Według J. Fijałka, po otrzymaniu zgody od kapituły nie wyjechał studiować, ale udał się na sobór do Ferrary, a w następnym roku w imieniu biskupa krakowskiego pojechał, wraz z Janem Elgotem i Jakubem z Szadka, na sobór do Bazylei. Fakt, że 7 I 1447 r. uzyskał wraz z Mikołajem Chebdą kolejną zgodę kapituły włocławskiej na studia zagraniczne, nie oznacza jednak, że wcześniej ich nie podjął. W postanowieniu kapituły mowa jest o pozwoleniu na kontynuację studiów na uniwersytecie niemieckim lub włoskim,

${ }_{93}$ ASB, Studio 126, k. 83v; J. F i j ł ł e k, Polonia, s. 96-97.

94 Tamże, s. 97: quomodo venerabilis dominus Nicolaus de Niewiesz decretorum doctor, dum stetisset in studio Bononiensi, ubi accepit insignia doctoratus, multo magis pro gloria huius Coronae Polonae et pro laude ecclesiarum, in quibus est intitulatus, quam pro necessitate suarum rerum elaboravisset.

95 H. B a r y c z, Polacy na studiach w Rzymie w epoce odrodzenia (1440-1600), Kraków 1938, s. 34; M. C z y ż a k, Kapituła, s. 373-375; P. D e m b i ń s k i, Poznańska kapituła, s. $577-$ 579; J. F i j ał e k, Polonia, s. 96-97; A. R a d z i miń s k i, Prałaci i kanonicy, t. I, s. 114.

96 J. Fij a ł e k, Polonia, s. 100-101; M. K o c z e r s k a, Zbigniew Oleśnicki i Kościół krakowski w czasach jego pontyfikatu (1423-1455), Warszawa 2004, s. 45-46; M. K o w a 1 c z y k ó w n a, Pniowski Jan, w: PSB XXVII (1983), s. 1; L. P o n i e w o z i k, Prałaci i kanonicy sandomierscy w okresie średniowiecza, Toruń 2004, s. 211-212; A. G ą s i o r o w s k i, Kanonicy włocławscy w najstarszej metryce kapitulnej (1435-1500), w: Duchowieństwo kapitulne w Polsce średniowiecznej i wczesnonowożytnej, Toruń 2000, s. 42; M. Z d a n e k, Jan Pniowski z Pniowa, w: Profesorowie Wydziału Prawa (jak w przyp. 52), s. 121-122.

${ }_{97}$ Immatrykulował się w 1425, a bakałarzem sztuk został w 1427 r. (MUK nr 25/001; NKP nr 27/28).

98 J. F ij a ł e k, Polonia, s. 100. 
z wyjątkiem Rzymu ${ }^{99}$. Latem 1447 r. Pniowski pojechał jako poseł Zbigniewa Oleśnickiego do papieża Mikołaja V do Rzymu w sprawie kapelusza kardynalskiego ${ }^{100}$, a stamtąd dopiero mógł się udać do Bolonii. W dniu 27 IV 1448 r. przystąpił już do egzaminu prywatnego z prawa kanonicznego, występując jako wicerektor ultramontanów (funkcję tę przejął po Mikołaju z Niewiesza, który zaraz po swym egzaminie publicznym wyjechał z Bolonii). Został jednogłośnie aprobowany, nie odnotowano przy tym informacji o udzieleniu mu jakiejkolwiek dyspensy (np. od lat studiów czy od prowadzenia wykładów lub repetitiones). Ponad tydzień później (4 V 1448) odbył egzamin publiczny w nawie katedry św. Piotra ${ }^{101}$. Należy zatem sądzić, że jego studia prawnicze trwały dłużej niż kilka miesięcy, przypuszczalnie studiował przez kilka lat. Przemawiałby za tym również fakt, że został później profesorem prawa na Uniwersytecie Krakowskim, a w lecie 1452 r. oraz w semestrze letnim i zimowym 1456/1457 pełnił funkcję jego rektora. Z biblioteki Jana, która (jak się przypuszcza) musiała być zasobna, znany jest jeden rękopis prawniczy, zawierający Decretales Grzegorza IX z komentarzem Bernarda z Parmy i Constitutiones Innocentego IV z komentarzem Bernarda z Compostelli. Rękopis ten nie pochodził jednak z Włoch, ale z Francji ${ }^{102}$.

W drugiej połowie lat pięćdziesiątych XV w. doktoraty w Bolonii zdobyło trzech młodych przedstawicieli polskich rodów możnowładczych. Pierwszym z nich był Marcin Gruszczyński herbu Poraj (zm. 1470), który 31 IV 1455 r. przystąpił do egzaminu prywatnego z prawa kanonicznego, a następnie otrzymał insygnia doktorskie $^{103}$. Studia prawnicze na uniwersytecie bolońskim zaczął, jak się przypuszcza, na początku lat pięćdziesiątych XV w., zaraz po studiach na Uniwersytecie Krakowskim (zapisał się na nie w 1443 r., brak informacji o uzyskaniu przez niego stopnia naukowego $)^{104}$. Niektórzy badacze przypuszczali, że po drodze był jeszcze w Rzymie, gdyż został akolitą papieskim ${ }^{105}$. Można zatem sądzić, że studiował prawo zgodnie ze statutami, tym bardziej że nie ma informacji o udzieleniu mu dyspensy. W czasie, gdy studiował w Bolonii, był już kanonikiem łęczyckim i włocławskim, a jego brat Jan - biskupem włocławskim. Kolejne beneficja Marcin uzyskiwał po zakończeniu studiów bolońskich. Były to scholasteria kruszwicka, prepozytura kruszwicka, kanonie gnieźnieńska i sandomierska, scholasteria płocka. Współpracował z bratem Janem (od 1464 r. arcybiskupem gnieźnieńskim) ${ }^{106}$.

\footnotetext{
99 Acta capitulorum, t. I, nr 1159-1160.

100 BP VI, nr 70.

101 ASB, Studio 126, k. 83v; J. F i j a ł e k, Polonia, s. 101.

102 Biblioteka Jagiellońska, rkps 379; zob. Catalogus codicum manuscriptorum, t. II,

103 LP, s. 17; S.A. S r o k a, Wykaz, s. 140 (Martinus de Polonia).

104 MUK nr 43h/102.

105 BP VI, nr 515, 549. Przypuszczano, że i stopień doktorski uzyskał w Rzymie
} s. $138-140$. (A. S z y m c z a k o w a, Szlachta sieradzka w XV wieku. Magnifici et generosi, Łódź 1998, s. 139; A. K o w a ls k a - P i e tr z a k, Prałaci i kanonicy kapituły łęczyckiej do schyłku XV wieku, Łódź 2004, s. 272; J. W i e s i oł o w s k i, Sędziwój z Czechła. Studium z dziejów kultury umysłowej Wielkopolski, Studia Źródłoznawcze 9, 1964, s. 82).

${ }_{106}$ A. K o w a 1 s k a - P i e tr z a k, Prałaci i kanonicy, s. 272-3; P. D e m b iń s k i, Poznańska kapituła, s. 426-427. 
W stosunkowo młodym wieku uzyskał boloński doktorat z prawa Jan Goślubski herbu Sulima (zm. 1500), bratanek arcybiskupa gnieźnieńskiego Władysława Oporowskiego ${ }^{107}$. W 1451 r. immatrykulował się na Uniwersytecie Krakowskim. Nie wiadomo, ile czasu tam studiował, gdyż nie figuruje w księdze promocji Wydziału Sztuk $^{108}$. Nie wiadomo też, jak długo trwały jego studia prawnicze i czy studiował prawo tylko w Bolonii. Przypuszcza się, że do Bolonii udać się mógł około połowy lat pięćdziesiątych XV w. ${ }^{109} \mathrm{Za}$ odbyciem pełnych studiów prawniczych (niekoniecznie tylko w Bolonii) przemawiałby fakt, że w Liber secretus nie odnotowano informacji o udzieleniu mu dyspensy od wymaganych zajęć. W dniu 6 X 1459 r. odbył się jego egzamin prywatny z prawa kanonicznego, a po nim zaraz otrzymał insygnia doktorskie ${ }^{110}$. Po zakończeniu studiów zdobył liczne beneficja - kanonie łęczycką (1462) i włocławską (1467), archidiakonat poznański (1468), kanonię gnieźnieńską (1482-1492), prepozyturę gnieźnieńską (1482) i kaliską (1494). Jego wykształcenie prawnicze zadecydowało zapewne o powierzeniu mu funkcji prokuratora króla polskiego w Kurii Rzymskiej (1468) czy o objęciu urzędu oficjała gnieźnieńskiego (1484-1493) i administratora sede vacante po śmierci arcybiskupa Zbigniewa Oleśnickiego (1493).

Jan Ostroróg herbu Nałęcz (zm. 1501), syn wojewody poznańskiego Stanisława ${ }^{111}$, również udał się do Bolonii przed rozpoczęciem kariery, a po kilkuletnich studiach, które odbył jednak, w odróżnieniu od dwóch wcześniej omówionych, w ośrodkach zagranicznych. Przypuszcza się, że w 1450 r. studiował w Wiedniu, natomiast w 1453 r. immatrykulował się w Erfurcie, gdzie studiował przez dwa lata (prawo?) ${ }^{112}$. Nie jest znana data jego przybycia do Bolonii, wiadomo jednak, że w 1. 1458-1459 piastował godność rektora ultramontanów. Dopełnił wymaganego statutami obowiązku prowadzenia wykładów z prawa kanonicznego - w latach akademickich 1458/1459 i 1459/1460 wykładał Dekret Gracjana w dni świąteczne ${ }^{113}$. W dniu 10 XII 1459 r. Ostroróg przystąpił do egzaminu prywatnego z prawa kanonicznego i cywilnego. Następnego dnia, za dyspensą kolegium doktorów, odbył bez opłat egzamin publiczny $\mathrm{z}$ obojga praw. Poniósł jednak koszty związane z wystawną ucztą ${ }^{114}$. Po powrocie do kraju związał się z dworem królewskim, pełnił misje dyplomatyczne z ramienia króla (do Rzymu w 1. 1464 i 1466/1467), znalazł się w komisji wydającej orzecze-

107 Tamże, s. 421-423; A. G ą s i o r o w s k i, I. S k i e r s k a, Średniowieczni oficjałowie gnieźnieńscy, Roczniki Historyczne 61, 1995, s. 82.

108 MUK nr 51h/130.

109 S. A. S ro k a, Wykaz, s. 142.

110 LP, s. 34: Johannes de Polonia examinatus fuit; et eodem instanti fuit doctoratus; S. A. S rok a, Wykaz, s. 142, podaje datę 6 X 1460 r.

111 Ostroróg Jan, w: PSB XXIV (1979), s. 503; J. W i e s i oł o w s k i, Ostroróg Jan, w: Wielkopolski słownik biograficzny, Warszawa-Poznań 1981, s. 538.

${ }_{112}$ Acten der Erfurter Universität, wyd. H. Weissenborn, Halle 1881, s. 238.

113 U. D a 11 a r i, I rotuli, s. 49.

114 LC 1451-1500, s. 65; LP, s. 34: 10 dec. Iohannes de Polonia examinatus fuit in utroque iure, et propter eius benemerita doctores donarunt omnem expensam ei; 11 dec. fuit dispensatum cum eo ut ista die poset fieri conventus publicus; et eadem die recepit insignia doctoratus per me; et fecit solepne prandium doctoribus colegii et pluribus aliis personis. 
nie w sprawie włączenia Mazowsza do Korony. W odróżnieniu od wcześniejszych polskich doktorów prawa z Bolonii, robił karierę świecką - został kolejno kasztelanem międzyrzeckim (1465), poznańskim (1474), starostą generalnym Wielkopolski (1493-1498), wojewodą poznańskim (1500). Niewiele można powiedzieć o wpływie bolońskich studiów na formację Jana Ostroroga jako prawnika. Pojawiają się ostatnio wątpliwości, czy rzeczywiście był autorem przypisywanego mu projektu reform państwa ${ }^{115}$.

Inny nieco model studiowania prawa reprezentują trzej kolejni Polacy, którzy na początku lat sześćdziesiątych XV w., już w dojrzałym wieku, zdobyli stopnie naukowe w Bolonii za dyspensą. Pierwszy z nich to wywodzący się zapewne z mieszczaństwa Wojciech z Nowego Miasta nad Pilicą (zm. 1487). Najprawdopodobniej studiował na Uniwersytecie Krakowskim (immatrykulacja w 1444 r.) ${ }^{116}$, zdobył doświadczenie jako notariusz w kancelarii biskupa Zbigniewa Oleśnickiego (1448-1454), został plebanem w Piotrawinie (1453) ${ }^{117}$. W dniu 12 VI 1458 r. złożył w Kurii Rzymskiej suplikę o pozwolenie na pobieranie dochodów ze swego beneficjum w czasie 7 lat studiowania prawa kanonicznego na uniwersytecie kurialnym lub innym ${ }^{118}$. Nie wiadomo, czy podjął studia w Rzymie, a po doktorat udał się do Bolonii, czy też rozpoczął studia od razu w Bolonii ${ }^{119}$. W każdym razie 31 I 1460 r. przystąpił do egzaminu prywatnego z prawa kanonicznego w Bolonii i zaraz po nim otrzymał insygnia doktorskie ${ }^{120}$. Nie został sprecyzowany przedmiot udzielonej mu przy tym dyspensy - prawdopodobnie dotyczyła studiowania zgodnie ze statutową liczbą lat albo prowadzenia wykładu lub repetitiones ${ }^{121}$. Wojciech nie zrobił kariery adekwatnej do bolońskiego doktoratu. Nie uzyskał wielu beneficjów; po powrocie do kraju starał się o scholasterię kielecką, a został kanonikiem wiślickim ${ }^{122}$. Mogło się do

${ }_{115}$ W. S o b o c i ń s k i, Memoriał Jana Ostroroga a początki reformacji w Polsce, Odrodzenie i Reformacja w Polsce 4, 1959, s. 35, uważał, że Ostroróg mógł dokonywać później zmian w utworze, nadając mu bardziej literacki charakter. Analizy dzieła dokonali W. Vo i sé, Doktryna polityczno-prawna Jana Ostroroga, Państwo i Prawo 6, 1954, s. 1036-1058; T. W y r w a, Les idées politiques et juridiques de Jan Ostroróg, humaniste polonais du XVe siècle, Revue Historique de Droit Français et Étranger, ser. 4, t. 53, 1975, nr 1, s. 5-35. Autorstwo Jana Ostroroga zakwestionował J. W i e s i o ł o w s k i, Ostroróg Jan, s. 538, stwierdzając, że tekst powstać musiał dopiero ok. 1530 r. Ostatnio zob. A. Wy c z a ń s k i, Memoriał Jana Ostroroga a postulaty egzekucyjne XVI wieku, w: Ludzie, Kościól, wierzenia. Studia z dziejów kultury i społeczeństwa Europy Środkowej (średniowiecze - wczesna epoka nowożytna), Warszawa 2001, s. 483-487.

${ }^{116}$ MUK nr 44h/088 (Albertus de Nove Myasto); zob. S. A. S r o k a, Wykaz, s. 141.

$117 \mathrm{~W} 1454$ r. starał się wzmocnić swoje prawo do posiadania tej parafii zabiegami o prowizję papieską (M. K o c z e r s k a, Zbigniew Oleśnicki, s. 59-61; BP VI, nr 785).

118 BP VI, nr 1264.

119 M. Koczerska, Zbigniew Oleśnicki, s. 61, podaje, że Wojciech udał się na studia do Rzymu bezpośrednio po śmierci Zbigniewa Oleśnickiego, ale nie przytacza na to dowodów źródłowych. Wśród Polaków studiujących w Rzymie nie wymieniają go S. A. S r o k a, Wykaz, s. 142, ani B. S c h w a r z, Kurienuniversität und stadtrömische Universität von ca. 1300 bis 1471, Leiden 2012 (Education and Society in the Middle Ages and Renaissance 46).

${ }^{120}$ LP, s. 36; S. A. S r o k a, Wykaz, s. 142 (Albertus de Polonia).

121 Nie podaje go w bolońskim spisie wykładowców U. D a 11 a ri, I rotuli.

122 S. A. S roka, Wykaz, s. 142. 
tego przyczynić jego pochodzenie społeczne, a także przeciwnicy, którzy usiłowali odebrać mu parafię w Piotrawinie ${ }^{123}$.

Stanisław Szeliga z Wojczyc herbu Dębno (zm. 1500) ${ }^{124}$ wpisał się na Wydział Sztuk w Krakowie w 1444 (po opłaceniu niepełnej składki) i w 1448 został bakałarzem, po czym zapewne na jakiś czas przerwał naukę (w 1449 r. kopiował w Sandomierzu Canones penitentiales), a następnie wrócił na Uniwersytet i w $1454 \mathrm{r}$. osiągnął stopień magistra ${ }^{125}$. Nie wiadomo, kiedy przybył do Bolonii na studia prawnicze. Nie można wykluczyć, że nastąpiło to wkrótce po krakowskim magisterium. Zapiska o zdobyciu przezeń w Bolonii stopnia licencjata dekretów 15 X 1460 r. nie zawiera bowiem wzmianki o udzieleniu mu dyspensy. Na egzaminie prywatnym dwóch członków kolegium dało mu ocenę negatywną ${ }^{126}$, co może wskazywać na jego niewystarczające przygotowanie (nie przeszkodziło to jednak w promocji, do której potrzebna była zwykła większość głosów). Stanisław nie uzyskał stopnia doktora, co mogło wynikać z braku odpowiednich środków finansowych. Wrócił do kraju, gdzie w 1. 1462-1463 pełnił funkcję zastępcy Jana Pniowskiego jako administratora apostolskiego diecezji krakowskiej. Później udał się do Rzymu, gdzie w 1465 r. studiował na uniwersytecie miejskim ${ }^{127}$. Obecny był tam także zimą 1470/1471 r. W czasie tego pobytu, zdaniem Marka Derwicha, mógł starać się o beneficja dla siebie, a także zabiegać o sukcesję dla Jagiellonów w Czechach. Zdaje się, że właśnie w Rzymie zapewnił sobie stopień doktora dekretów (uzyskany po 1466, a przed 1472 r. $)^{128}$. Połączenie studiów bolońskich z pobytem w Rzymie wskazuje na dążenie Stanisława do zrobienia kariery kościelnej, co mu się zresztą udało - został plebanem w Iłży (przed 1469), uzyskał prowizję na kanonię gnieźnieńską i krakowską (1470), kanonię sandomierską (1472), był altarystą w katedrze na Wawelu (1473), a także plebanem w Koniemłotach (od 1483). Ściśle związana z wykształceniem prawniczym była funkcja oficjała sandomierskiego, pełniona przez niego w 1. 1473-1498. Świadectwem formacji intelektualnej Stanisława są rękopisy, głównie o charakterze teologicznym, które podarował w 1477 r. klasztorowi benedyktynów na Łyśćcu ${ }^{129}$.

${ }^{123}$ W 1462 uwięziono go u krakowskich bernardynów i odebrano mu tę parafię, a w 1464 r. udało mu się uwolnić i udać do Rzymu, gdzie składał supliki o przywrócenie beneficjum (M. K o c z e r s k a, Zbigniew Oleśnicki, s. 61).

${ }^{124}$ M. D e rw i c h, Stanisław z Wojczyc i benedyktyni łysogórscy, Acta Universitatis Nicolai Copernici, Historia XXVI, Nauki Humanistyczno-Społeczne, z. 240 (1992), s. 173185; S. A. S ro ka, Wykaz, s. 142-143; J. W i ś n i ew s k i, Katalog prałatów i kanoników sandomierskich od 1186 do 1926 r., tudzież sesje kapituły sandomierskiej od 1581 do 1866 r., Radom 1926, s. 289; M. H or n ow s k a, H. Z d z i t o w i e c k a - J a s i eń s k a, Zbiory rękopiśmienne w Polsce średniowiecznej, Warszawa 1947, s. 324.

125 MUK, nr 44h/129; NKP, nr 48/8, 54/3.

${ }^{126}$ LP, s. 38: 1460 I sem. 15 oct. Lancislaus de Polonia habuit duas reprobatorias. Fuit aprobatus.

${ }^{127}$ Nie wiadomo, czy studiował prawo czy teologię; nie wynika to z dokumentu BP VII, nr 199, na który powołuje się S. A. S r o k a, Wykaz, s. 142-143.

${ }_{128}$ M. D e rw i c h, Stanisław z Wojczyc, s. 185-187.

129 Były tam Biblia sacra Veteris et Novi Testamenti z prologami św. Hieronima i glosami z Mikołaja z Liry, Postylla Mikołaja z Liry, Dykcjonarz moralny Piotra Berchoriusza i Żywot Chrystusa Ludolfa z Saksoni (M. Hornowska, H. Z d z i t ow i e cka-J a s i eń ska, Zbiory, s. 324, 340, 341, 343-345, 358; M. D e r w i c h, Stanisław z Wojczyc, s. 181-182). 
Można sądzić, że w swojej bibliotece posiadał także dzieła prawnicze potrzebne w pracy oficjała.

Marcin ze Słupcy (zm. 1462), który w 1461 r. zdobył doktorat z prawa, również wywodził się z mieszczaństwa ${ }^{130}$. Studiował sztuki wyzwolone na Uniwersytecie Krakowskim (immatrykulował się w 1436, a stopień magistra zdobył w 1441 r.) $)^{131}$. Przez kolejne lata pracował jako wykładowca w poznańskiej szkole katedralnej (do 1442), następnie w szkole parafialnej w Słupcy, a od 1447 r. znowu przy katedrze. Potem wykładał na Uniwersytecie Krakowskim, czego świadectwem jest jego wykład Heroid Owidiusza z 1456 r., zapisany przez Jana z Szabic. Pisał również utwory wierszowane, w których wykorzystywał zwroty z Persjusza, Owidiusza i Wergiliusza. Nie wiadomo, ile czasu trwały jego studia prawnicze w Bolonii. Można sądzić, że nie były to studia pełne, gdyż 27 I $1461 \mathrm{r}$. za dyspensą przystąpił do egzaminu prywatnego i tego samego dnia otrzymał insygnia doktorskie ${ }^{132}$. Być może studia prawnicze miały związek z jego karierą kościelną. Jeszcze przed uzyskaniem doktoratu został bowiem kanonikiem wileńskim. Nie wiadomo, w którym momencie objął kościół parafialny we Wrociszewie (30 XII 1462 r. został on określony jako wakujący po śmierci naszego Marcina ze Słupcy).

W dość młodym wieku uzyskał doktorat prawa w Bolonii Andrzej Oporowski (zm. 1483), bratanek arcybiskupa Władysława Oporowskiego ${ }^{133}$. Odbył on najpierw pięcioletnie studia na Wydziale Sztuk Uniwersytetu Krakowskiego (wpisał się w 1455 r., a stopień magistra osiągnął w 1460 r. $)^{134}$. W 1461 r. jako prezbiter diecezji gnieźnieńskiej starał się o pozwolenie na studiowanie prawa na jakimkolwiek uniwersytecie, a rok później, już jako boloński student prawa kanonicznego, prosił papieża o pozwolenie na studiowanie przez 5 lat prawa rzymskiego w Bolonii lub na innym uniwersytecie ${ }^{135}$. Doktorat obojga praw, ale za dyspensą udzieloną przez kolegium doktorów prawa kanonicznego i cywilnego, zdobył jeszcze w grudniu 1462 r. Studia prawnicze Andrzeja Oporowskiego trwałyby więc najwyżej niecałe półtora roku. W przypadku prawa kanonicznego został zwolniony z obowiązku prowadzenia wykładów albo repetitiones z Dekretu oraz z uczęszczania na wykład

${ }^{130}$ K. We y s e n h off - B rożk ow a, Marcin ze Słupcy, w: PSB XIX (1974), s. 573; S. A. S rok a, Wykaz, s. 143; K. S t o p k a, Szkoły katedralne metropolii gnieźnieńskiej w średniowieczu. Studia nad kształceniem kleru polskiego w wiekach średnich, Kraków 1994, s. 88; J. W i e s i o ł o w s k i, Kolekcje historyczne w Polsce średniowiecznej XIV-XV wieku, Wrocław 1976, s. 83; V. A li ša u s k a s, T. J a s z c z ołt, L. J o v a iš a, M. P a kn y s, Lietuvos katalikų dvasininkai XIV-XVI w., Vilnius 2009, s. 224. W dawniejszej literaturze przyjmowano, że Marcin uzyskał doktorat dekretów w Padwie (S. W i n d a k i e w i c z, Materiały, s. 135; J. O c h m a ń s k i, Biskupstwo wileńskie w średniowieczu. Ustrój i uposażenie, Poznań 1972, s. 34).

${ }_{131}$ MUK, nr 37/20; NKP nr 41/18 (magisterium, dopisek: decretorum doctor).

132 LP, s. 40: 27 Iun. [1461] Martinus de Lupeza de Polonia, canonicus Vilnensis dispensatus fuit; examinatus fuit et approbatus, nemine discrepante, et illico doctoratus.

133 T. S t o la r c z y k, Oporowscy herbu Sulima. Kariera rodziny możnowładczej w późnośredniowiecznej Polsce, Łódź 2013, s. 163-177; P. D e m b i ń s k i, Poznańska kapituła, s. 358-360; I. S ułk ow s k a - K u ra s i ow a, Polska kancelaria królewska w latach 14471506, Wrocław 1967, s. 18-19.

${ }_{134}$ NKP, nr 58/18, 60/2.

135 BP VI, nr 1629, 1765. 
z Dekretu ${ }^{136}$. W roku akademickim 1462/1463 Andrzej wymieniony jest jednak jako wykładowca Dekretu w dni świąteczne ${ }^{137}$. Zwolnienie mogło wynikać z faktu, że w grudniu nie zdążył jeszcze przeprowadzić całego rocznego cyklu wykładów. Nie wiadomo, czy uzyskał zwolnienie również w przypadku prawa cywilnego, gdyż w Liber secretus iuris caesarei brakuje wpisów od 29 X 1462 do stycznia 1463 r. ${ }^{138} \mathrm{~W}$ dniu 11 XII 1462 r. Andrzej przystąpił do egzaminu prywatnego z prawa kanonicznego i cywilnego, a cztery dni później odbył uroczysty egzamin publiczny w katedrze ${ }^{139}$. Wydaje się, że w jego przypadku nie chodziło o formację prawniczą, ale sam stopień doktorski potrzebny do kariery kościelnej, którą rozpoczął jeszcze przed wyruszeniem do Italii. Był już wtedy kanonikiem krakowskim (1460) i kantorem włocławskim (1461). Po uzyskaniu doktoratu kumulowal kolejne beneficja, a w końcu został biskupem warmińskim (1471), przemyskim (1479) i włocławskim (1481). Związał się z dworem monarszym, pełnił funkcję sekretarza królewskiego (1464-1466), jeździł w misjach dyplomatycznych, a od 1479 r. był podkanclerzym koronnym.

Niewiele wiadomo o kolejnym graduacie, Tomaszu z Polski, który 20 XII 1465 r. przystąpił do egzaminu prywatnego z prawa kanonicznego i cywilnego i tego samego dnia otrzymał insygnia doktorskie ${ }^{140}$. S. A. Sroka zidentyfikował go jako Tomasza ze Szwarocina, plebana w Gąbinie ${ }^{141}$. Należy przypuszczać, że Tomasz odbył kilkuletnie studia prawnicze (nie wiadomo, czy tylko w Bolonii), gdyż pełnił funkcję rektora ultra- i citramontanów, a brak też wzmianki o udzieleniu mu dyspensy ${ }^{142}$. Przy egzaminie z prawa kanonicznego został aprobowany jednomyślnie, natomiast na egzaminie z prawa cywilnego otrzymał dwa głosy negatywne. Po uzyskaniu doktoratu pozostał jeszcze w Bolonii, gdzie w roku akademickim 1465/1466 wykładał Dekretały oraz Digestum vetus w dni świąteczne ${ }^{143}$. Był w Bolonii jeszcze 4 VI 1467 r., kiedy to

${ }^{136}$ LC 1451-1500, s. 84, przyp. 276: Die VI decembris (1462) dispensatum fuit d. Andrea de Opporov de Polonia, rectore ultramontanorum dignissimo, eo quod non legit vel repetiit, nec audivit Decretum per annum et eodem possit in utroque iure examinari; wydawca LP, s. 44, pominął część dotyczącą dyspensy.

${ }_{137}$ U. D a 11 a r i, I rotuli, s. 60; por. S. A. S ro k a, Wykaz, s. 144.

138 Por. LC 1451-1500, s. 84, przyp. 276.

139 LP, s. 45: Die XI decembris examinatus fuit predictus $d$. Andreas in utroque iure, presentatus in iure canonico per d. Antonium de S. Pietro, Antonium de Grassis, Io. de Salla et per me Marcum [de Muzolis]; et habuit in punctis c. Nemo potest XVI, q. I et c. I De testa; et ita se habuit, quod ab omnibus, nemine discrepante, fuit approbatus. Die XV decembris publice in eclesia cathedrali fuit doctoratus et insignia doctoratus dedit d. Antonius de S. Petro predictus, tam in iure civili quam in iure canonico.

${ }^{140}$ LP, s. 52: 1465 II sem 20 dec. Thomas de Polonia rector Universitatis, nemine discrepante fuit aprobatus; LC 1451-1500, s. 97: [20 XII 1465] Dominus Tomas de Polonia, rector utriusque universitatis propter carentiam rectoris citramontani, fuit subiectus privato examini in iure civili et etiam in iure canonico aulandus. Et fuit aprobatus ab omnibus, exceptis duobus; et illico accepit gradum.

141 S. A. S r o k a, Wykaz, s. 154.

${ }^{142}$ Statuty bolońskiego uniwersytetu prawników przewidywały, że rektor powinien studiować prawo przez co najmniej pięć lat, mieć ukończone 25 lat i dysponować odpowiednimi środkami na swoje utrzymanie (Statuti, s. 49).

143 U. D a 11 a ri, I rotuli, s. 68. 
wystąpił jako świadek na egzaminie z teologii Stanisława z Szadka. Określony został wtedy jako doktor prawa kanonicznego, bakałarz teologii i archidiakon ${ }^{144}$.

Również Władysław z Poznania (Głębocki) herbu Bylina (zm. 1508) ${ }^{145}$ zdał egzamin prywatny jako rektor ultra- i citramontanów i uzyskał doktorat z prawa kanonicznego w Bolonii 16 III 1467 r. ${ }^{146}$ Wcześniej studiował sztuki wyzwolone na Uniwersytecie Krakowskim (wpisał się w 1456 r., nie wiadomo nic o uzyskanym przez niego stopniu $)^{147}$. Na studia prawnicze do Bolonii udał się, gdy był już kanonikiem poznańskim (od 1461), kruszwickim (1457-1460) oraz archidiakonem pomorskim (1463-1468). W 1465 r. kapituła poznańska udzieliła mu zgody na podjęcie studiów prawniczych we Włoszech. Można zatem przypuszczać, że w Bolonii studiował krótko. Fakt, że został promowany jednomyślnie, wskazuje, że musiał mieć odpowiednie przygotowanie. Wprawdzie jako rektor, zgodnie ze statutami, powinien studiować przez pięć lat prawo, ale udzielona mu przed egzaminem prywatnym dyspensa, której przedmiot nie został niestety sprecyzowany, wskazywałaby, że nie odbył jednak pełnych studiów. W roku akademickim 1466/1467 wykładał w Bolonii Dekretały w dni świąteczne ${ }^{148}$. Zdobytą wiedzę prawniczą mógł wykorzystać po powrocie jako lektor prawa kanonicznego w Gnieźnie (1468). W 1493 r. kapituła gnieźnieńska wyznaczyła go wraz z Jakubem Boksicą do korekty statutów kapitulnych. O formacji prawniczej Władysława Głębockiego mogą świadczyć dwa dzieła prawnicze (Liber institutorum oraz Casus summarios super decretales) podarowane przezeń bibliotece kapituły gnieźnieńskiej ${ }^{149}$.

Dziersław z Karnic (zm. 1494) ${ }^{150}$, który doktorat obojga praw w Bolonii zdobył w 1471 r., studiował najpierw sztuki wyzwolone na Uniwersytecie Krakowskim (wpisał się w 1448, a stopień bakałarza sztuk uzyskał w 1453 r.) $)^{151}$. Doświadczenie i pewną formację mógł zdobyć, pracując w konsystorzu za oficjała krakowskiego Rafała ze Skawiny. Nie wiadomo dokładnie, kiedy rozpoczął studia prawnicze w Rzymie, które kontynuował równolegle z karierą kurialną (w 1. 1455, 1452 i 1465 występował jako prokurator w Kurii, a 25 VI 1470 r. został określony jako antiquus curialis). W 1. 1456 i 1457 określano go jako bakałarza prawa kanonicznego i studenta prawa cywilnego w Rzymie, a w 1.1465 i 1468 - jako studenta prawa cywilnego w Rzymie ${ }^{152}$. Pobyt

${ }^{144}$ LP, s. 52, przyp. 284; C. P i a n a, Ricerche su le Università di Bologna e di Parma, Firenze 1963, s. 102.

145 P. D e m b iń s k i, Poznańska kapituła, s. 701-703.

146 LP, s. 57: 24 febr. [1467] Vvaldislaus de Polonia rector utriusque Universitatis Studii Bonon. ac archidiaconus Robdislamensis, dispensatus fuit; 16 martii examinatus fuit aprobatusque, nemine discrepante, et eadem die doctoratus; S. A. S ro k a, Wykaz, s. 145, zidentyfikował go jako Władysława z Głęboczka.

${ }^{147}$ MUK, nr 56k/158; por. P. D e m b iń s k i, Poznańska kapituła, s. 701.

148 U. D a 11 a ri, I rotuli, s. 91.

149 K. S t o p k a, Szkoła katedralna, s. 185; J. R y 1, Biblioteka katedralna w Gnieźnie, Archiwa, Biblioteki i Muzea Kościelne 23, 1976, s. 227.

150 S. A. S rok a, Wykaz, s. 146; M. D. K ow als k i, Proventus, s. 195.

151 MUK nr 48h/150; NKP nr 53/3.

152 B. S c h w a r z, Kurienuniversität, s. 741-742. O funkcjach prokuratorów w Kurii szerzej C. S c h u c h a rd, Die Deutschen an der päpstlichen Kurie im späten Mittelalter (1378-1447), Tübingen 1987 (Bibliothek des Deutschen Historischen Instituts in Rom 65). 
w Kurii z pewnością ułatwił mu zdobywanie beneficjów w Polsce - scholasterii płockiej, prepozytury św. Michała w Płocku i kanonii krakowskiej. W dniu 3 II $1471 \mathrm{r}$. Dziersław został jednomyślnie promowany w Bolonii na egzaminie prywatnym z prawa kanonicznego i otrzymał insygnia doktorskie ${ }^{153}$. Nie wiadomo, czego dotyczyła udzielona mu dyspensa - być może zwolnienia z obowiązku wykładów lub repetitiones ${ }^{154}$. Dopisek w Metryce Uniwersytetu Krakowskiego wskazuje, że w Bolonii uzyskał w 1471 r. stopień doktora obojga praw, po czym wrócił do Polski $^{155}$. Jego egzamin nie jest jednak odnotowany w Liber secretus iuris caesarei ${ }^{156}$. Biorąc pod uwagę działalność Dziersława i jego obowiązki związane z funkcją kolektora Kamery Apostolskiej w Królestwie Polskim (1470-1472), można przypuszczać, że nie studiował w Bolonii wcale albo studiował bardzo krótko, a przyjechał tam głównie po stopień doktora. Późniejsza jego kariera związana była głównie z Kurią Rzymską, w której przebywał od 1480 r. do śmierci. O jego formacji prawniczej (raczej rzymskiej niż bolońskiej) może świadczyć rękopis przywieziony ze studiów i ofiarowany kapitule płockiej ${ }^{157}$.

O żadnej dyspensie nie ma natomiast wzmianki w przypadku doktoratu z prawa kanonicznego uzyskanego 15 V 1476 r. przez Jana syna Jakuba z Polski ${ }^{158}$. Identyfikuje się go z Janem z Wysokiej (zm. 1504) z diecezji krakowskiej ${ }^{159}$. Jego pochodzenie społeczne nie jest znane. Przed wyjazdem do Bolonii studiował sztuki wyzwolone na Uniwersytecie Krakowskim (wpisał się w 1463, bakałarzem został w 1465, a magistrem - w 1470 r. $)^{160}$. Na studia prawnicze mógł wyjechać do Włoch w drugiej połowie 1474 r., gdyż wiosną i latem tego roku czynił, jak świadczą zapiski w aktach rektorskich, duże zakupy. Jednomyślne promowanie na egzaminie prywatnym z prawa kanonicznego wskazuje na jego dobre przygotowanie, a brak informacji o udzieleniu jakiejkolwiek dyspensy wskazywałby na odbycie pełnych studiów prawniczych (może nie tylko w Bolonii). Mógł zacząć studiować prawo w Krakowie i dopiero w $1474 \mathrm{r}$. wyjechać do Bolonii. Mógł też zacząć studiować w Bolonii, wrócić w 1474 r. do Krakowa i ponownie pojechać do Włoch. Wątpliwości te mogłyby rozstrzygnąć dodatkowe źródła dotyczące jego działalności w 1. 1470-1476. Dalsza kariera Jana jako doktora prawa związana była z Wydziałem Prawa Uniwersytetu Krakowskiego.

${ }^{153}$ LP, s. 65: 3 febr. [1471] Desilaus de Polonia dispensatus fuit; 5 febr. examinatus et approbatus fuit, nemine discrepante.

154 Nie podaje go wśród wykładowców U. D a 11 a ri, I rotuli.

155 MUK nr 48h/150: postea de anno Domini M CCCC L XXI Bononie de mense Januario factus doctor utriusque iuris venit Poloniam.

156 S. A. S r o k a, Wykaz, s. 146, przypuszczał, że Dziersław mógł doktorat prawa cywilnego uzyskać w Rzymie.

157 Zawierał repetitiones adwokatów konsystorskich z lat 1468 i 1469, a pochodził z Rzymu (A. Ve tul a n i, Średniowieczne rękopisy, s. 377-379; W. G ó r a ls k i, Wkład kapituły katedralnej w Płocku do rozwoju kultury umysłowej miasta do XVI wieku, Studia Płockie 32, 2004, s. 169).

${ }^{158}$ LP, s. 81: 15 maii, Iohannes Iacobi de Polonia examinatus et doctoratus fuerit, et ab omnibus, nemine discrepante, approbatus; et ego Iohannes de Sala sibi tradidi insignia.

159 S. A. S r o k a, Wykaz, s. 147; D. W ó j c i k - Z e g a, Jan z Wysokiej, w: Profesorowie Wydziału Prawa (jak w przyp. 52), s. 163-165.

160 MUK nr 63h/158; NKP nr 65/30, 70/10. 
Dnia 10 II 1478 r. nostryfikował swój dyplom boloński, a następnie został włączony do grona profesorów. Wykładał Liber Sextus i Klementyny, a od 1491 r. Dekret Gracjana. Sprawował też godność dziekana Wydziału Prawa w 1. 1485 i 1495. Z racji swojego wykształcenia był konsyliarzem rektorów Jana Sakrana z Oświęcima (1494/1495) i Wojciecha z Pniew (1497/1498). Uzyskał altarie u św. Aleksego oraz u Wszystkich Świętych w Krakowie, był plebanem w Koprzywnicy i wreszcie kanonikiem krakowskiej kolegiaty Wszystkich Świętych.

W latach osiemdziesiątych XV w. trzech Polaków uzyskało stopnie naukowe $\mathrm{z}$ prawa $\mathrm{w}$ Bolonii, przystępując do egzaminu prywatnego za dyspensą. $\mathrm{W}$ przypadku pierwszego z nich, Abrahama Zbąskiego (zm. 1528) ${ }^{161}$, siostrzeńca biskupa poznańskiego Uriela Górki (co skwapliwie odnotował w swoim diariuszu Gaspare Codibò ${ }^{162}$ ), rektora ultramontanów w 1482 r., mamy do czynienia z rodzinną tradycją studiów bolońskich. Już Uriel Górka (biskup od 1479 r.) studiował w Bolonii od 1463 r. (aczkolwiek nie uzyskał żadnego stopnia naukowego) ${ }^{163}$. Abraham w czasie swych studiów był już kanonikiem poznańskim (od 1476) i gnieźnieńskim (od 1480). Nie wiadomo, gdzie studiował wcześniej ani ile czasu trwały jego studia prawnicze. Kolegium doktorów prawa cywilnego w Bolonii udzieliło mu dyspensy od obowiązku studiowania przez wymagane statutami lata oraz od obowiązku prowadzenia repetitiones (dopiero w drugim głosowaniu, gdyż w pierwszym był jeden głos sprzeciwu $)^{164}$. W przypadku prawa kanonicznego nie ma wzmianki o udzieleniu mu dyspensy. W czasie egzaminu z prawa cywilnego Abraham otrzymał negatywne oceny od dwóch członków kolegium doktorskiego ${ }^{165}$. Z prawa kanonicznego został promowany jednomyślnie. W dniu $10 \mathrm{~V} 1483 \mathrm{r}$. odbył egzamin publiczny z obojga praw. Wiąże się z nim zdarzenie, które mogłoby wskazywać, że pozytywny wynik egzaminów Abrahama był z góry zakładany. Wicearchidiakon boloński chciał bowiem we wcześniej już ułożonej mowie na wręczenie insygniów doktorskich powiedzieć, że Abraham zarówno z prawa cywilnego, jak i kanonicznego promowany był nemine discrepante. W tej sytuacji przewodniczący kolegium doktorów prawa cywilnego zarządził głosowanie, w wyniku którego wicearchidiakon uzyskał zgodę na ogłoszenie, że Abraham został jednogłośnie promowany na doktora

${ }^{161}$ P. D e m b iń s k i, Poznańska kapituła, s. 338-339.

162 Diario bolognese, s. 46: Abraam Polonus nepos Uriellis Poznanicensis [!] episcopi factus est rector Ultramontanorum et Artistarum. S. A. S r o k a, Polacy w Bolonii, s. 669, przypuszczał, że Uriel w czasie swoich studiów bolońskich mógł mieszkać w domu Gaspara Codibó, ale nie ma na to dowodów źródłowych.

${ }^{163}$ P. D e m b i ń s k i, Poznańska kapituła, s. 682 (z powołaniem na kopiariusz z Archiwum Archidiecezjalnego w Poznaniu); o studiach bolońskich nie wspomina J. G a r b a c i k, Górka (z Górki) Uriel, w: PSB VIII (1959), s. 421-422.

${ }^{164}$ LC 1451-1500, s. 261: Die VII eiusdem mensis, convocato collegio in loco consueto, dispensatum fuit cum $d$. Abraam, rectore dignissimo dominorum ultramontanorum, quod, non obstante quod [non] studuerit per tempus debitum, possit graduari; item non obstante quod non repecierit; item quod eadem die possit subire examen in iure civili et canonico. In qua congregatione interfuerunt novem doctores et habuit fabas albas octo et unam nigram in primo partito; in $2^{\circ}$ et $3^{\circ}$ habuit novem fabas albas et sic omnes albas.

165 Tamże: Die VIII presentatus fuit michi priori predictus d. Abram per promotores suos et ei asignavi diem $X$ pro punctis et examine, qui in examine habuit duas reprobatorias. 
obojga praw ${ }^{166}$. Do sytuacji tej nawiązuje też wzmianka w Liber secretus iuris pontifici, że kandydat uzyskał promocję „niezasłużenie”167. Znaczący wydaje się także fakt, że Abraham wyjechał z Bolonii już dwa dni po doktoracie, co odnotował Gaspare Codibó $^{168}$. Po powrocie do kraju uzyskał jeszcze kanonię włocławską (1486). Później porzucił jednak karierę kościelną i już przed 1489 r. został tenutariuszem babimojskim, a w 1. 1516-1528 był kasztelanem bydgoskim.

Kolejny Polak, Jan z Szyszek (zm. 1505) ${ }^{169}$, za dyspensą przystąpił 15 X 1489 r. do egzaminu prywatnego z prawa kanonicznego i tego samego dnia otrzymał insygnia doktorskie $^{170}$. Przyjechał do Bolonii już w dojrzałym wieku i mając za sobą studia na Uniwersytecie Krakowskim (wpisał się w 1464 r. ${ }^{171}$, a ze stopniem magistra jest potwierdzony źródłowo od 1482 r.). Zdobył doświadczenie jako notariusz publiczny i adwokat konsystorski w Gnieźnie, później zaś (1482-1484) pisarz na dworze biskupa płockiego. Posiadał już beneficja - był wikariuszem katedry płockiej (1476-1484) i plebanem w Królewie (od 1481). Na studia do Bolonii mógł się udać po 1484 r. Liber secretus nie podaje, czego dotyczyła dyspensa - lat studiów czy prowadzenia wykładu. Po powrocie Jan kontynuował karierę kościelną. Został kanonikiem płockim (1491) i prepozytem pułtuskim (1493-1503).

Również Jan syn Jana z Dąbrówki (zm. 1513) ${ }^{172}$ z diecezji poznańskiej, który uzyskał doktorat prawa kanonicznego w Bolonii 20 VI 1489 r. ${ }^{173}$, udał się na studia

166 Tamże: Eadem die examinatus in iure canonico, fuit aprobatus, nemine discrepante; sed quia in eadem oratione fienda per eximium utriusque iuris doctorem Antonium Siculum, vice archidiaconum non poterant apte adaptari verba orationis, ut dicerent, quod fuerit aprobatus in iure canonico nemine discrepante et in iure civili fuerunt due reprobatorie, fuit visum doctoribus omnibus iuris civilis et iuris canonici, quod ego prior ponerem partitum, quibus placet, quod, non obstante quod in iure civili habuerit duas reprobatorias, vice archidiaconus dicat in iure civili in eadem oratione, quod fuerit etiam aprobatus nemine discrepante, ex gratia ponat fabam albam; quibus displicet, ponat nigram. In quo partito interfuerunt XII doctores et optentum fuit partitum, nemine discrepante; propter quod vice archidiaconus aprobavit eum d. Abbraham nemine discrepante non solum in iure canonico, sed etiam dixit et comprobavit eum nemine discrepante etiam in iure civili; et isto modo in utroque iure, nemine discrepante, fuit aprobatus.

167 LP, s. 96: Habraam, rector scolarium ultramontanorum, examinatus et conventuatus fuit, et fuit doctoratus in utroque iure, licet inmerito.

168 Diario bolognese, s. 48: Abram Polonus rector $X$ die 10 mai utriusque iuris doctor factus; pro eo spopondi et sequenti die abiit; zob. S. A. S ro k a, Polacy w Bolonii, s. 670.

169 S. A. S r o k a, Wykaz, s. 149.

${ }^{170}$ LP, s. 109: Ioannes Bouyethii de Schisski de diocesi Plotensi in Polonia dispensatus fuit; - - 15 oct. examinatus fuit et ab omnibus, nemine discrepante, approbatus; vicarius archidiaconi [Francisci de Ruvere protonotarii apostolici] pronuntiavit et constituit doctorem; S. A. S rok a, Wykaz, s. 149.

171 MUK nr 64h/125.

172 S. A. S ro k a, Wykaz, s. 149; A. G ą s i o r o w s k i, Kanonicy włocławscy, s. 41, 49, 51. Zob. P. D e m b ińs k i, Poznańska kapituła, s. 473, który doktorat boloński uzyskany w 1467 r. przypisuje Janowi Słapowi z Dąbrowy herbu Drogosław, synowi Piotra. Doktorat taki nie jest odnotowany w Liber secretus iuris pontifici (cytowany przez tego badacza S. W in d a k i e w i c z, Informacja, s. 134-135, podaje jednak rok 1489).

173 LP, s. 109: 19 iun., Ioannes Dambrocha de Polonia dispensatus fuit; 20 iun. examinatus et, nemine discrepante, approbatus, licenciatus et graduatus fuit. 
prawnicze w dojrzałym wieku. Miał za sobą studia na Wydziale Sztuk Uniwersytetu Krakowskiego (immatrykulacja w 1470, magisterium w 1479 r.) ${ }^{174}$. Na podstawie udzielonej mu dyspensy można przypuszczać, że jego studia prawnicze nie obejmowały pełnego kursu albo nie dopełnił obowiązku prowadzenia wykładów lub repetitiones. Po powrocie do kraju uzyskał archidiakonat pomorski w kapitule włocławskiej (1496-1513) i pełnił funkcję prokuratora tej kapituły (1498-1500).

W latach dziewięćdziesiątych XV w. stopnie naukowe z prawa otrzymało w Bolonii czterech Polaków, w tym trzech za dyspensą. W przypadku Jana Filipowicza z Wilna (zm. 1524), który zdobył doktorat prawa kanonicznego 4 IV 1495 r. ${ }^{175}$, nie wiadomo, jak długo studiował prawo ani jaką odbył wcześniej edukację na poziomie uniwersyteckim. Ze względu na prawdopodobne pochodzenie plebejskie stopień doktora praw był mu potrzebny w karierze kościelnej. Ułatwiły ją nawiązane w Bolonii kontakty (uzyskał tytuł protonotariusza papieskiego i wicekomesa papieskiego). Od 1497 r. występował jako świadek na dokumentach biskupów wileńskich, a w 1501 r. został kanonikiem wileńskiej kapituły katedralnej. Pełnił też funkcję sekretarza Zygmunta Starego jako wielkiego księcia litewskiego (od 1508) i króla polskiego (od 1517). W 1519 r. król udzielił mu prezenty na biskupstwo kijowskie, co potwierdziła w następnym roku prowizja papieska ${ }^{176}$.

Niewiele można powiedzieć o studiach albo karierze Polaka określonego jako Landislaus de Polonia, który 27 I 1496 r. zdobył doktorat prawa kanonicznego za dyspensą. Wiadomo, że był pochodzenia szlacheckiego i wywodził się z diecezji włocławskiej ${ }^{177}$.

Jan Salomon (zm. 1528), syn rajcy krakowskiego Piotra Salomona ${ }^{178}$, przystąpił 12 XII 1496 r. w Bolonii do egzaminu prywatnego z prawa kanonicznego i został jednomyślnie promowany. Tego samego dnia złożył egzamin prywatny z prawa cywilnego (z jednym głosem sprzeciwu), po czym otrzymał insygnia doktorskie ${ }^{179}$. Wcześniej studiował sztuki wyzwolone na Uniwersytecie Krakowskim (zapisany w 1484, magistrem został w 1491 r. $)^{180}$. Karierę rozpoczął dzięki wpływowemu ojcu. Od 1490 r. był altarystą w krakowskim kościele Mariackim. Na nauki do Włoch udał

${ }^{174}$ MUK nr 70e/085; NKP nr 79/4.

${ }^{175}$ LP, s. 124: Iohannes Filipibus de diocesi Vilnensi de Lamania dispensatus fuit; 8 apr. examinatus, approbatus nemine discrepante, et doctoratus per Iacobum Bovium.

${ }^{176}$ K. R. P r o k o p, Biskupi kijowscy obrządku łacińskiego XIV-XVIII w. Szkice biograficzne, Biały Dunajec - Ostróg 2003, s. 34-35.

${ }^{177}$ LP, s. 127: 23 ian. nobilis et egregius scolaris Landislaus de Polonia dispensatus fuit; - - 27 ian. examinatus et doctoratus fuit; et fuit aprobatus nemine discrepante. W Liber notarii pod tą datą jest wymieniony Stanislaus de Polonia diocesis Wladislaviensis (cyt. za: LP, s. 127, przyp. 669). S. A. S ro k a, Wykaz, s. 154-155, wskazując na większą precyzję zapisków w aktach notarialnych, daje pierwszeństwo imieniu Stanisław, a zwraca też uwagę, że również Stanisław z Wojczyc został w Liber secretus zniekształcony jako Lancislaus de Polonia.

178 W. B u k o w s k i, Salomon Jan, w: PSB XXXIV (1992-1993), s. 379; S. A. S ro k a, Wykaz, s. 151.

179 LP, s. 128: 12 dec. Ioannes q. Petri Salamonis, Polonus de Cracovia, examinatus, graduatus et doctoratus fuit, et aprobatus nemine discrepante; LC 1451-1500, s. 374, przyp. 285: ipsum [d. Johannem de Apolonia] approbaverunt unanimiter, excepta una voce reprobatoria.

180 MUK nr 84e/037; NKP nr 91/7. 
się w 1492 r. Brak wzmianki o udzieleniu mu dyspensy świadczyłby o odbyciu pełnych studiów. Po powrocie zdobywał kolejne beneficja: kanonię gnieźnieńską (1500) i krakowską (1501), prepozyturę skalbmierską (1505), parafię w Kocku (1510) oraz dziekanię sandomierską (1517).

Marcin Łukasz z Wilkanowa, syn starosty bratiańskiego Adama ${ }^{181}$, do Bolonii udał się po zakończeniu studiów na Wydziale Sztuk Uniwersytetu Krakowskiego (zapisany w 1486, magistrem został w 1490 r.) $)^{182}$. W dniu 14 II 1495 r., po wcześniejszych dyspensach udzielonych przez kolegium doktorów prawa kanonicznego i cywilnego, został jednomyślnie promowany i otrzymał stopień doktora obojga praw ${ }^{183}$. W przypadku prawa cywilnego dyspensa dotyczyła faktu, że nie prowadził wykładów ani repetitiones ${ }^{184}$. W następnym roku, 21 IV 1496 r., uzyskał jeszcze doktorat teologii w Sienie ${ }^{185}$. Gdy wrócił do kraju, został kanonikiem warszawskim (1500-1507).

\section{PODSUMOWANIE}

Stopnie naukowe z prawa uzyskało w Bolonii w XV w. łącznie 29 Polaków. Warto zwrócić uwagę na to, jak rozkładała się liczba promowanych na poszczególne dekady. W pierwszym dziesięcioleciu XV w. - mamy jednego doktora, w drugim - dwóch, w latach dwudziestych - czterech, w trzydziestych nie ma odnotowanego żadnego, w czterdziestych jest znowu czterech, w pięćdziesiątych - trzech, w sześćdziesiątych - sześciu, w siedemdziesiątych - dwóch, w osiemdziesiątych trzech i dziewięćdziesiątych - czterech. Dla porównania, w Padwie doktorat z prawa w pierwszej dekadzie XV w. uzyskało dwóch Polaków, na przełomie drugiej i trzeciej dekady - kolejnych dwóch, a w latach czterdziestych - jeszcze jeden, a w drugiej połowie XV w. nie odnotowano tam już żadnych Polaków promowanych z prawa ${ }^{186}$.

${ }^{181}$ S. A. S r o k a, Wykaz, s. 151; L. K ró 1 i k, Kapituła kolegiacka w Warszawie do końca XVIII wieku, Warszawa 1990, s. 193.

${ }_{182}$ MUK nr 86e/083; NKP nr 90/1.

183 LP, 1451-1500, s. 124: 14 Febr. Martinus Lucas Vvilkanovv dioecesis Plocensis in Polonia dispensatus fuit; 2 Febr. examinatus et conventuatus; approbatus nemine discrepante; doctoratus in utroque iure; LC 1451-1500, s. 362: Die 14 mensis Februarii dispensatum fuit cum d. Luca de Polonia, qui obtinuit per omnes fabas albas, nemine penitus discrepante, legittime convocato collegio - -. Die XXI eiusdem mensis, congregato legittime colegio in sufficienti numero, aprobatus fuit nobilis et peritissimus scolaris d. Lucas de Apolonia antedictus, nemine discrepante. Et iuravit legittime more consueto, $d$. Sigismondo de Magnanis vices meas gerente, cum ego interesse nequiverim ob antianatus officium.

184 ASB, Studio 26 (Liber notarii iuris caesarei), k. 246r; LC 1451-1500, s. 362, przyp. 249: d. Lucas de Apolonia exposuit se velle subire examen - - sibi obstabat quod non legit lectiones sui magistri, neque repetiit legem vel rubricam.

185 S. A. S r o k a, Wykaz, s. 151; G. M in u c c i, Le lauree dello Studio Senese alla fine del secolo XV, Milano 1981, s. 33.

186 Byli to: Andrzej Łaskarzyc doktor dekretów (1402), Paweł Włodkowic licencjat dekretów (1408), Mikołaj Kicki doktor dekretów (1419), Władysław Oporowski licencjat (między VI a X 1419) i doktor dekretów (5 XI 1419), Jan Lasocki licencjat dekretów (1447). Pominięty został Wawrzyniec z Wrocławia określony jako Laurentius Saxonis de Polonia, o którego związkach z Polską niewiele wiadomo. Zob. J. F i j a ł e k, Polonia, s. 2-8, 20-26, 55-56, 49-53; Acta graduum academicorum gymnasii Patavini ab anno 1406 ad annum 1450, red. G. Zonta, I. Brotto, t. II, Padova 1970, s. 258, nr 2150; D. G a 11 o, Lauree inedite, s. 33. 
W trzeciej i czwartej dekadzie XV w. prawniczy Uniwersytet Padewski wyraźnie więc ustępował w preferencjach Polaków miejsca Bolońskiemu, a w drugiej połowie XV w. Uniwersytet Padewski przestał być miejscem uzyskiwania stopni naukowych z prawa przez Polaków ${ }^{187}$. Stosunkowo małą liczbę Polaków promowanych z prawa w Bolonii na początku XV w. można wiązać z kryzysem, jaki przechodziła uczelnia w związku z sytuacją polityczną - schizmą i wewnętrznymi walkami o władzę w mieście. Prześladowania dotknęły wtedy również profesorów, którzy jako obywatele bolońscy byli zaangażowani w politykę miejską. Pod zarzutem zdrady aresztowany został wybitny kanonista Gaspare Calderini, a profesor prawa cywilnego Bartolomeo da Saliceto został dwukrotnie skazany na wygnanie (1389 i 1399) ${ }^{188}$. W związku z tą sytuacją nastąpił spadek liczby egzaminów z prawa kanonicznego. O ile w 1402 r. odbyło się 14 egzaminów publicznych, o tyle w 1406 r. - już tylko jeden $^{189}$. Sytuacja ta, a także dążenie władz miejskich do większej kontroli nad studium oraz niedostateczne finansowanie przyczyniły się do tego, że po śmierci Giovanniego da Legnano (1383) ${ }^{190}$ zabrakło równie wybitnych kanonistów. Według ustaleń Berarda Pio, w 1. 1418-1427 zaczęła wzrastać liczba przystępujących do egzaminów prywatnych z prawa kanonicznego z około 8 do 10 rocznie, głównie za sprawą większego napływu ultramontanów ${ }^{191}$. Ponowny rozkwit uniwersytetu nastąpił jednak dopiero pod koniec lat czterdziestych XV w. dzięki działaniom podjętym przez papieża Mikołaja V i jego dyspozycjom na rzecz wykładowców i studentów oraz dzięki wysłanemu do Bolonii legatowi, kardynałowi Bessarionowi ${ }^{192}$.

Trudniej jest wskazać preferencje Polaków w wyborze Bolonii jako miejsca samych studiów prawniczych niezakończonych zdobyciem stopnia naukowego. Na obecnym etapie badań można wskazać co najmniej kilkunastu Polaków, którzy studiowali prawo w Bolonii, nie uzyskując tam stopnia naukowego ${ }^{193}$. Nasza wiedza o nich

Żadnych Polaków promowanych z prawa w drugiej połowie XV w. nie odnotowują: Acta graduum academicorum gymnasii Patavini ab anno 1451 ad annum 1460, red. M. P. Ghezzo, Padova 1990; Acta graduum academicorum gymnasii Patavini ab anno 1461 ad annum 1470, red. G. Pengo, Padova 1992; Acta graduum academicorum gymnasii Patavini ab anno 1471 ad annum 1500, red. E. Martelozzo-Forin, Roma-Padova 2001.

187 Por. L. R o s s e t t i, Spunti, s. 248.

188 B. P i o, Lo Studium e il Papato tra XIV e XV secolo, w: Politica e 'Studium': nuove prospettive e ricerche, Bologna 2005 (Studi e memorie per la storia dell'università di Bologna, seria nowa, t. 10), s. 158-160; H. J. B e c k e r, Calderini Gaspare, w: DBI XVI (1973), s. 605606; G. O rl a n d e 11 i, Bartolomeo da Saliceto, w: DBI VI (1964), s. 766-768.

189 B. P i o, La peregrinatio academica nell'età dello scisma: studenti di diritto canonico a Bologna fra XIV e XV secolo, w: Identità cittadine e aggregazioni sociali in Italia, secoli XI-XV, Trieste 2012, s. 126-127.

190 A. B a r t o c c i, Giovanni da Legnano († 1383), w: Autographa, t. I, cz. 1: Giuristi, giudici e notai (sec. XII-XVI med.), Bologna 2012, s. 87-101; B. P i o, Oldrendi Giovanni (Giovanni da Legnano), w: DBI LXXIX (2013), s. 196-200.

191 B. P i o, La peregrinatio, s. 130.

192 A. L. Tro m be t t i - B u dri es i, L'esame di laurea, s. 176.

193 Tomasz Strzempiński, Mikołaj Kicki, Władysław Oporowski, Grzegorz Cieniawa, Jakub z Kutna, Jan z Niewiesza, Stanisław z Brudzewa, Uriel Górka, Jan ze Zdziaru, Jan Lubrański, Paweł Szydłowiecki. Badacze z reguły zaliczają do Polaków studiujących prawo kanoniczne w Bolonii również Mikołaja i Andrzeja Koperników, mimo że byli wpisani do nacji 
często sprowadza się do odnotowania samego faktu studiów. Na przykład o kapłanie diecezji poznańskiej Tomaszu Strzempińskim, synu Jaśka, wiadomo tylko, że 25 XI 1410 r. studiował w Bolonii ${ }^{194}$. Mikołaj Kicki (zm. 1429) archidiakon gnieźnieński (i współrodowiec biskupa poznańskiego Andrzeja z Gosławic, który doktoryzował się w Padwie) oraz Władysław Oporowski rozpoczęli studia prawnicze w Bolonii, ale potem przenieśli się do Padwy i tam uzyskali stopień doktora ${ }^{195}$. Przyszły (od 1498) biskup poznański Jan Lubrański doktorat dekretów zdobył w Rzymie ${ }^{196}$, Paweł Szydłowiecki zaczął studiować prawo kanoniczne w Bolonii (1496), ale doktorat uzyskał (1501) w Ferrarze ${ }^{197}$. Niekończenie studiów prawniczych w Bolonii stopniem tam uzyskanym w wielu wypadkach mogło być powodowane brakiem wystarczających środków finansowych, o czym była już mowa. Za przykład mogą posłużyć także studia Grzegorza Cieniawy z Mysłowic (zm. 1460/1461), syna rajcy kazimierskiego Piotra Cieniawy ze Stradomia. Grzegorz w 1433 r. uzyskał na Uniwersytecie Krakowskim stopień magistra sztuk i bakałarza dekretów. W 1437 r. wyjechał na studia prawnicze, otrzymawszy list polecający od Jana Elgota do profesorów w Bolonii, Padwie i Paryżu. O tym, że studiował prawo w Bolonii, świadczy przepisany tam przez niego w 1437 r. rękopis zawierający Recollecta super Sexto Domenika da San Gimignano ${ }^{198}$. W 1439 r. wrócił do Krakowa, gdzie ukończył studia prawnicze, zdobywając w 1440 licencjat, a w 1441 r. - doktorat dekretów. Od 1444 r. wykładał na Uniwersytecie Krakowskim ${ }^{199}$.

Można przypuszczać, że w latach, kiedy Polacy pełnili funkcje rektorów lub wicerektorów ultramontanów (np. pod koniec lat czterdziestych XV w.), obecni byli w Bolonii również inni studenci polscy. W 1447 r., gdy rektorem citra- i ultramontanów

niemieckiej, zob. S. A. S r o k a, Doktoraty Polaków na uniwersytecie w Ferrarze w pierwszej połowie XVI wieku, Roczniki Historyczne 80, 2014, s. 158-159. Nie można za Polaków uznać wszystkich wymienionych w spisie rektorów nacji polskiej, zamieszczonym w tomie Laudatio Bononiae, s. 428-431.

${ }^{194}$ Nie chodzi tu o imiennika, późniejszego biskupa krakowskiego (J. F i j a ł e k, Polonia, s. 31; por. P. D e m b iń s k i, Poznańska kapituła, s. 676, przyp. 844).

${ }_{195}$ Mikołaj Kicki w 1415 studiował w Bolonii, a w 1418 i 1419 r. w Padwie (J. F i j a ł e k, Polonia, s. 49; o studiach bolońskich: C. P i a n a, Nuovi documenti, s. 687, nr 1615; D. G a 11 o, Lauree inedite, s. 20; L. R o s s e t i, Spunti, s. 247). Władysław Oporowski w 1416 studiował w Bolonii, w Padwie zaś między V a X 1419 uzyskał licencjat dekretów, a 27 X 1419 r. - doktorat dekretów (J. F i j a ł e k, Polonia, s. 55-56; D. G a 11 o, Lauree inedite, s. 33). Andrzej Łaskarzyc z Gosławic herbu Godziemba mógł, zdaniem J. F i j a łk a, Polonia, s. 20-26, udać się na studia prawnicze do Padwy już na przełomie 1402 i 1403, jego obecność poświadczona jest tam 10 XI 1403, a promowany na doktora dekretów został 22 II 1405 r.

196 P. D e m b i ń s k i, Poznańska kapituła, s. 441-443; L. H a j d u k i e w i c z, Lubrański Jan, w: PSB XVIII (1973), s. 81-84; I. S ułk ow s ka-Ku ra s i owa, Polska kancelaria, S. 139.

197 S. A. S rok a, Szydłowiecki Paweł, w: PSB XLIX (2013-2014), s. 574; te n że, Doktoraty, s. 157.

${ }^{198}$ W rękopisie tym wspomniał o swoich kłopotach finansowanych w czasie studiów: per Gregorium de Myslowicze alias de Zawada continuantem studium Bononiae a. d. 1437 gravissimis expensis, quia pauperimus fuit (J. F i j a ł e k, Polonia, s. 85).

199 Tamże, s. 84-86; B. Wy r o z u m s k a, Grzegorz Cieniawa, w: PSB IX (1960-1961), s. 84-85; M. Z d a n e k, Grzegorz Cieniawa z Mysłowic, w: Profesorowie Wydziału Prawa (jak w przyp. 52), s. 81-82. 
był Mikołaj Chebda z Niewiesza, prawo kanoniczne studiował w Bolonii kanonik włocławski Jakub z Kutna ${ }^{200}$, a być może (choć brak na to potwierdzenia źródłowego) także brat Mikołaja, Jan z Niewiesza ${ }^{201}$. Na początku lat pięćdziesiątych w Bolonii studiowali Stanisław z Brudzewa herbu Pomian, syn wojewody sieradzkiego ${ }^{202}$, oraz Jan ze Zdziaru kanclerz płocki (1449-1455) i późniejszy oficjał płocki (1476$1482)^{203}$, w połowie lat sześćdziesiątych - Uriel Górka herbu Łodzia, syn wojewody poznańskiego i późniejszy biskup poznański ${ }^{204}$. Grupa Polaków, którzy studiowali prawo w Bolonii w XV w. bez uzyskania stopnia naukowego, musiała być w istocie jeszcze liczniejsza. Należy się spodziewać, że dalsze badania archiwalne ujawnią nowe nazwiska. Można sądzić, że większość Polaków, którzy nie kończyli studiów stopniem naukowym, przebywała krótko w Bolonii, gdyż większość studentów studiowała tam najwyżej kilka lat, nie odbywając pełnych studiów ${ }^{205}$.

Analizując dyspensy uzyskane przez Polaków promowanych z prawa w Bolonii w XV w., można uznać, że przynajmniej dla 16 z nich Bolonia raczej nie była rzeczywistym czy najważniejszym miejscem uzyskania formacji prawniczej. Ośmiu uzyskało dyspensy od obowiązku studiowania przez przewidziane statutami lata lub prowadzenia wykładu albo repetitiones ${ }^{206}$, kolejnych ośmiu uzyskało dyspensy, których przedmiot nie został sprecyzowany ${ }^{207}$, ale należy sądzić, że i oni nie odbyli pełnych studiów. Także wśród pozostałych Polaków, przystępujących do egzaminu prywatnego bez żadnego zwolnienia, część mogła swoje studia prawnicze odbywać też poza Bolonią (tak jak Piotr Wolfram), ale brakuje niestety przeważnie źródeł, aby to stwierdzić (nic prawie nie wiemy o przebiegu studiów Jakuba z Polski czy Tomasza z Polski). Ponieważ w XV w. postępowało odchodzenie od statutowych wymogów co do czasu studiów, dyspensy stawały się coraz częstsze, przybierając na sile zwłaszcza od lat trzydziestych i czterdziestych (spośród Polaków pierwsi uzyskali je Adam z Będkowa w 1423 i Gotard z Gurby w 1424 r.), by pod koniec stulecia stać się właściwie rutynową praktyką. W związku z tym coraz częściej przestawano podawać informacje o udzielonych dyspensach ${ }^{208}$. Nie zawsze jednak

200 J. F i j a ł e k, Polonia, s. 103; BP VI, nr 423.

201 Tak sądził K. D o la, Wrocławska kapituła katedralna w XV wieku. Ustrój, skład osobowy, działalność, Lublin 1983, s. 339, a za nim L. P o n i e w o zi k, Prałaci, s. 205; nie wspominają natomiast o studiach J. F i j a ł e k, Polonia, s. 94, oraz M. C z y ż a k, Kapituła, s. 342-344.

${ }^{202}$ BP VI, nr 423 (26 IX 1450); zob. P. D e m b i ń s k i, Poznańska kapituła, s. 649.

${ }^{203}$ BP VI, nr 634 (1 VII 1452); zob. A. R a d z i m i ń s k i, Prałaci i kanonicy, t. I, s. 192-193.

204 Zob. wyżej, przyp. 163.

${ }^{205}$ A. L. Tro m b e t t i - B u dri e s i, L'esame di laurea, s. 144.

${ }^{206}$ Dyspensy od kolegium doktorów prawa kanonicznego otrzymali: Adam z Będkowa, Gotard z Gurby, Zygmunt Giżycki i Andrzej Oporowski, a od kolegium doktorów prawa cywilnego: Mikołaj z Mirzyńca, Mikołaj Chebda, Abraham Zbąski i Marcin Łukasz Wilkanowski.

207 Wojciech Piotrawiński z Nowego Miasta, Marcin ze Słupcy, Władysław z Głęboczek, Dziersław z Karnic, Jan z Dąbrowy, Jan z Szyszek, Jan Filipowicz z Wilna, Landislaus de Polonia.

${ }^{208} \mathrm{~W}$ przypadku prawa cywilnego w $1.1378-1500 \mathrm{z}$ dyspens przy przystępowaniu do egzaminu skorzystało 57,95\% ultramontanów. W 1. 1398-1407 z dyspensy skorzystało 18 spośród 139 egzaminowanych, w 1. 1448-1457: 70 spośród 128, a w 1. 1488-1497: 112 spośród 120 (A. L. Tr o m bet t i - B u d r i e s i, L'esame di laurea, s. 179, 182-184). 
sposób uzyskiwania stopni naukowych przez Polaków odzwierciedlał tę ogólną tendencję do zwolnień. Spośród czterech Polaków, którzy uzyskali doktoraty w latach czterdziestych XV w., dwóch otrzymało dyspensy (Mikołaj z Mirzyńca i Zygmunt Giżycki), w latach pięćdziesiątych natomiast żaden z trzech promowanych Polaków nie miał dyspensy (Jan Ostroróg został tylko zwolniony z opłaty za egzamin); w latach sześćdziesiątych zwolnienia miało czterech z sześciu promowanych Polaków, w latach siedemdziesiątych - jeden spośród dwóch (Dziersław z Karnic), a drugi nie (Jan z Wysokiej), w latach osiemdziesiątych i dziewięćdziesiątych z ulg korzystali wszyscy promowani Polacy (odpowiednio trzej i czterej).

Polacy, w przypadku których można mówić o pełnych studiach prawniczych i przynajmniej częściowej formacji bolońskiej, byli z reguły przedstawicielami możnych rodów i udawali się do Bolonii u progu swojej kariery w stosunkowo młodym wieku ${ }^{209}$. Byli to bliscy krewni hierarchów kościelnych, jak Wojciech i Filip, bratankowie biskupa poznańskiego, a potem prymasa Wojciecha Jastrzębca, należący do młodszego pokolenia (zaczynający edukację w Krakowie w latach czterdziestych XV w.), Marcin Gruszczyński, brat biskupa włocławskiego Jana, nieco młodsi od niego (studiujący w Krakowie w latach pięćdziesiątych) Jan Goślubski i Andrzej Oporowski, bratankowie arcybiskupa gnieźnieńskiego Władysława Oporowskiego czy należący do kolejnej generacji Abraham Zbąski, siostrzeniec biskupa poznańskiego Uriela Górki. W przypadku Andrzeja Oporowskiego chodziło jednak bardziej o stopień, a formacja prawnicza była tylko częściowa, gdyż jego studia w Bolonii mogły trwać najwyżej półtora roku. Zwieńczone stopniem doktorskim studia mogły stanowić wstęp do przyszłej kariery biskupiej (jak w przypadku Andrzeja Oporowskiego i Jana Goślubskiego). Analogie można wskazać wśród graduatów z Padwy. Był wśród nich Władysław Oporowski, wysłany zapewne przez ojca, wojewodę łęczyckiego Mikołaja, na kilkuletnie studia zagraniczne w związku z planowaną karierą kościelną. Młody Oporowski udał się najpierw do Wiednia na Wydział Sztuk (immatrykulacja w 1413, bakalaureat w 1415 r.), potem studiował prawo w Bolonii,

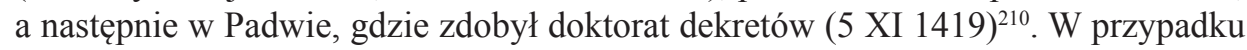
Jana Ostroroga, przedstawiciela możnej rodziny, który został wysłany na kilkuletnie studia zagraniczne w młodym wieku i uzyskał doktorat obojga praw, chodziło o zapewnienie kariery świeckiej. Studia Jana wpisywały się w tradycję rodzinną Ostrorogów - w XV w. wszyscy synowie i wnukowie Sędziwoja z Ostroroga (dziada doktora Jana) studiowali na uniwersytetach; razem z Janem zapisał się w Erfurcie jego stryjeczny brat Dobrogost ${ }^{211}$.

Przedstawiciele drugiej grupy, do której można zaliczyć 11 polskich graduatów, byli w dojrzałym wieku, posiadali beneficja i pełnili ważne funkcje kościelne lub państwowe. Z reguły studiowali w Bolonii dość krótko. Swoją formację prawniczą

209 Za taki można uznać wiek poniżej 30 lat, gdy znaczna część Polaków uzyskiwała doktoraty z prawa w wieku lat 30-40. Ponieważ możliwe są tylko szacunkowe oceny wieku (i to nie we wszystkich przypadkach), nie można obliczyć średniego wieku uzyskiwania doktoratu.

${ }^{210}$ D. G a 11 o, Lauree inedite, s. 11; por. J. F i j a ł e k, Polonia, s. 54-56; P. D e m b ińs k i, Poznańska kapituła, s. 698.

211 A. G ą s i o r o w s k i, Panowie z Ostroroga. Wprowadzenie, w: Wielkopolscy Ostrorogowie, Ostroróg 1998, s. 10; t e n ż e; Dobrogost z Lwówka, w: PSB XXIV (1979), s. 499. 
często zdobyli wcześniej i zanim sięgnęli po uniwersytecki stopień, mieli już za sobą praktykę jako notariusze, pracownicy kancelarii, prokuratorzy w Kurii itp. Taki model studiowania spotykany jest $\mathrm{w}$ różnych pokoleniach i wśród przedstawicieli różnych grup społecznych, reprezentują go zarówno przedstawiciele możnowładztwa i szlachty, jak Mirosław z Brudzewa (doktorat w drugiej dekadzie XV w.), Adam z Będkowa (doktorat w trzeciej dekadzie) czy też nieco młodszy Gotard z Gurby (doktorat w trzeciej dekadzie), a zwłaszcza Mikołaj Chebda z Niewiesza (ok. 45-50 lat w momencie doktoratu w 1448 r., jednak w jego przypadku można mówić o formacji bolońskiej, ze względu na kilkuletni pobyt w Bolonii), Jan Pniowski (ok. 40 lat w momencie doktoratu w 1448 r.), należący do jego pokolenia Zygmunt Giżycki (ok. 35-40 lat w momencie doktoratu w 1446 r.) czy wreszcie urodzeni później od nich Jan z Szyszek (ok. 40 lat w momencie doktoratu w 1489 r.) i Jan z Dąbrówki (ok. 35 lat w momencie doktoratu w 1489 r.). Zdobywających stopnie naukowe w Bolonii synów mieszczańskich spotykamy w różnych dekadach i z reguły mieli oni w momencie promocji ponad 30 lat (Piotr Wolfram, Marcin ze Słupcy, Wojciech z Nowego Miasta). Wyjątkiem od tej reguły jest Jan Salomon, syn wpływowego rajcy krakowskiego, który udał się do Bolonii w młodym wieku, bezpośrednio po uzyskaniu stopnia magistra sztuk w Krakowie, i mógł uzyskać bolońską formację prawniczą.

Polacy studiujący prawo w Bolonii i tam zdobywający stopień naukowy studiowali wcześniej prawo $\mathrm{w}$ innych ośrodkach. $\mathrm{W}$ pierwszych dekadach XV w. mieli za sobą najczęściej studia w Pradze (Piotr Wolfram, Mirosław z Brudzewa, Gotard z Gurby) lub w Padwie (Piotr Wolfram, Wojciech Jastrzębiec). Promowani w Bolonii w drugiej i trzeciej dekadzie XV w. coraz częściej odbyli wcześniej pełne studia na Wydziale Sztuk w Krakowie (staje się to w zasadzie regułą w drugiej połowie XV w.). Od lat czterdziestych pojawiają się osoby studiujące wcześniej w Rzymie (Mikołaj z Mirzyńca, Wojciech z Nowego Miasta, Dziersław z Karnic). Wiązało się to $\mathrm{z}$ faktem, że dopiero od $1443 \mathrm{r}$. wznowiły swą działalność rzymskie uniwersytety miejski i kurialny, po okresach długich przerw związanych przede wszystkim z nieobecnością papieży ${ }^{212}$. Decyzja o uzyskaniu stopnia naukowego w Bolonii wynikała w przypadku tych ludzi z pewnością z prestiżu bolońskiego doktoratu z prawa.

W drugiej połowie XV w. wśród Polaków studiujących i zdobywających stopnie naukowe z prawa $\mathrm{w}$ Bolonii szczególnie silnie reprezentowane są środowiska katedralne Poznania, Gniezna i Płocka. Stosunkowo mniejszy udział środowiska krakowskiego można thumaczyć faktem, że wielu z jego przedstawicieli robiło karierę dzięki pracy w kancelarii królewskiej, od niższych stanowisk dochodząc z czasem do najwyższych i uzyskując dzięki protekcji królewskiej ważne stanowiska kościelne i dochodowe beneficja ${ }^{213}$.

Spośród 29 polskich graduatów prawa z Bolonii w XV w. pięciu zostało profesorami prawa Uniwersytetu Krakowskiego. W drugiej i trzeciej dekadzie XV w.

${ }^{212}$ B. S c h w ar z, Kurienuniversität, s. 2; C. Frova, M. Mig li o, „Studium Urbis” e „Studium Curiae” nel Trecento e nel Quattrocento: linee di politica culturale, w: Roma e lo Studium Urbis. Spazio urbano e cultura dal quattro al seicento, Roma 1992 (Publicazioni del Archivio di Stato, Saggi 22), s. 27.

${ }^{213}$ Większość pracowników kancelarii koronnej w 1. 1447-1506 wywodziła się z Małopolski (I. S ułk ow ska-K u r a s i ow a, Polska kancelaria, s. 43, 49). 
było trzech profesorów Uniwersytetu Krakowskiego ze stopniem naukowym zdobytym w Bolonii (Piotr Wolfram, Wojciech Jastrzębiec i Adam z Będkowa); w latach pięćdziesiątych - jeden (Jan z Pniowa, trzykrotny rektor) i w latach osiemdziesiątych i dziewięćdziesiątych również jeden (Jan z Wysokiej). W Bolonii studiował także, choć nie uzyskał stopnia naukowego, Grzegorz Cieniawa. Widać, że o ile w początkowym okresie funkcjonowania Uniwersytetu Krakowskiego potrzebni byli ludzie po przynajmniej krótkim pobycie w najważniejszych wówczas uniwersytetach prawniczych i ze zdobytym tam stopniem, o tyle w drugiej połowie stulecia uczelnia krakowska mogła się już bez nich obyć.

Studia i stopień doktorski w Bolonii ułatwiały dalszą karierę, ale nie decydowały o niej, zwłaszcza w kraju. Z pewnością szanse na zrobienie kariery w otoczeniu kurialistów czy w samej Kurii Rzymskiej zwiększały się w przypadku osób, które w czasie studiów zdołały nawiązać bliższe kontakty z późniejszymi kardynałami czy nawet papieżami ${ }^{214}$. Wydaje się jednak, że nie należy przeceniać roli Bolonii jako miejsca rzeczywistej formacji prawników polskich w XV w. O takiej formacji można mówić jedynie w przypadku tych, którzy odbyli w Bolonii pełne (lub co najmniej kilkuletnie) studia. Spośród omówionych powyżej 29 Polaków, którzy zdobyli stopnie z prawa w Bolonii, można wskazać dziewięciu, w przypadku których z pewnością można mówić o formacji prawniczej bolońskiejej15, u kolejnych pięciu można ją podejrzewać ${ }^{16}$. Wydaje się, że dla kolejnych piętnastu Bolonia nie była głównym miejscem formacji prawniczej, a raczej tylko zdobywania stopni ${ }^{217}$.

Kwestią wartą zbadania, choć trudną do zrealizowania ze względu na zniszczenie archiwum krakowskiego Collegium Iuridicum w pożarze w 1719 r. ${ }^{218}$, byłaby analiza treści wykładów prowadzonych na Wydziale Prawa Uniwersytetu Krakowskiego przez profesorów wykształconych w Bolonii i ocena, czy widoczny w nich był wpływ bolońskich doświadczeń. Należałoby także zbadać, czy wpływy bolońskiej szkoły

${ }^{214}$ Mechanizm taki pokazany jest w zawartej w Translatio sancti Floriani literackiej opowieści o biskupie krakowskim Idzim i jakimś biskupie mogunckim (dominus Maguntinus), późniejszym papieżu, zawierających ze sobą pakt w czasie studiów w Padwie. Wydaje się, że opowieść ta odzwierciedla raczej realia piętnasto- niż dwunastowieczne, zwłaszcza że zachowała się w rękopisach z XV w., ale kwestia ta wymagałaby odrębnych badań (Translatio Sancti Floriani, wyd. W. Kętrzyński, Monumenta Poloniae historica, t. IV, Lwów 1884, s. 755-762). Za zwrócenie uwagi na tę opowieść dziękuję profesorowi Jackowi Banaszkiewiczowi.

215 Wojciech i Filip Jastrzębcowie (formacja prawnicza padewsko-bolońska), Mikołaj z Mirzyńca, Mikołaj Chebda z Niewiesza, Marcin Gruszczyński, Jan Goślubski, Jan Ostroróg, Stanisław z Wojczyc, Jan z Wysokiej, Jan Salomon.

216 Jakub z Polski (za bolońską formację przemawiałby brak dyspensy i studiowanie na początku XV w., kiedy stopnie uzyskiwano po odbyciu pełnych studiów, ale z drugiej strony nie wiemy, czy studiował prawo tylko w Bolonii), Jan z Pniowa, Stanisław z Wojczyc, Abraham Zbąski (pełnił funkcję rektora), Tomasz z Polski (pełnił funkcję rektora, brak dyspensy).

217 Piotr Wolfram z Krakowa, Mirosław z Brudzewa, Adam z Będkowa, Gotard z Gurby, Zygmunt Giżycki, Dziersław z Karnic, Wojciech Piotrawiński, Andrzej Oporowski, Marcin ze Słupcy, Władysław z Poznania (Głębocki), Jan z Szyszek, Jan syn Jana z Dąbrówki, Jan Filipowicz z Wilna, Marcin Łukasz z Wilkanowa, Landislaus de Polonia.

${ }_{218}$ W. Ur u s z c z a k, Wydział Prawa Uniwersytetu Krakowskiego i jego profesorowie w latach 1364-1780, w: Profesorowie Wydziału Prawa (jak w przyp. 52), s. XIII. 
prawniczej widoczne są w twórczości pozauniwersyteckiej krakowskich kanonistów, obejmującej m.in. traktaty, consilia, kazania oraz mowy ${ }^{219}$.

\section{BIBLIOGRAFIA}

Acta capitulorum nec non iudiciorum ecclesiasticorum selecta, t. I, wyd. B. Ulanowski, Kraków 1894.

Acta graduum academicorum gymnasii Patavini ab anno 1406 ad annum 1450, red. G. Zonta, I. Brotto, t. II, Padova 1970.

Acta graduum academicorum gymnasii patavini ab anno 1451 ad annum 1460, red. M. P. Ghezzo, Padova 1990.

Acta graduum academicorum gymnasii patavini ab anno 1461 ad annum 1470, red. G. Pengo, Padova 1992.

Acta graduum academicorum gymnasii patavini ab anno 1471 ad annum 1500, red. E. Martellozzo-Forin, Roma-Padova 2001.

Acta nationis Germanicae Universitatis Bononiensis, wyd. F. Friedlaender, C. Malagola, Berolini 1887.

Acten der Erfurter Universität, wyd. H. Weissenborn, Halle 1881.

Ališauskas V., T. Jaszczołt, L. Jovaiša, M. Paknys, Lietuvos katalikų dvasininkai XIV-XVI w., Vilnius 2009.

Ascheri M., I diritti del Medioevo italiano. Secoli XI-XV, Roma 2000.

Bartocci A., Giovanni da Legnano ( $†$ 1383), w: Autographa, t. I, cz. 1: Giuristi, giudici e notai (sec. XII-XVI med.), Bologna 2012.

Barycz H., Polacy na studiach w Rzymie w epoce odrodzenia (1440-1600), Kraków 1938.

Becker H. J., Calderini Gaspare, w: Dizionario biografico degli Italiani, t. XVI (1973).

Belloni A., L'insegnamento giuridico nelle università italiane, w: Luoghi e metodi di insegnamento giuridico nell'Italia medievale (secoli XII-XIV), Galatina 1989.

Belloni A., Professori giuristi a Padova nel secolo XV. Profili bio-bibliografici, Frankfurt am Main 1986.

Bukowski W., Salomon Jan, w: Polski słownik biograficzny, t. XXXIV (1992-1993).

Bullarium Poloniae, wyd. I. Sułkowska-Kuraś, S. Kuraś, t. VI, Romae-Lublin 1998.

Catalogus codicum manuscriptorum medii aevii Latinorum qui in Bibliotheca Jagellonica Cracoviae asservantur, t. II, red. M. Kowalczyk, Wrocław 1982.

Chachaj M., Promocje doktorskie biskupów, prałatów i kanoników katedralnych krakowskich na Uniwersytecie Bolońskim od schyłku XV do końca XVII wieku, w: Kościół katolicki w Małopolsce w średniowieczu i we wczesnym okresie nowożytnym, Kielce-Gdańsk 2001.

Chartularium studii Bononiensis, t. I-XV, Bologna 1909-1987.

Codex diplomaticus Universitatis studii generalis Cracoviensis, t. I, Kraków 1870.

Czwojdrak B., Jastrzębce w ziemi krakowskiej i sandomierskiej do połowy XV wieku, Kraków 2007.

Czyżak M., Kapituła katedralna w Gnieźnie w świetle metryki z lat 1408-1448, Poznań 2003.

Czyżak M., Legat książkowy archidiakona Mikołaja Kickiego dla katedry gnieźnieńskiej. Przyczynek do kultury intelektualnej duchowieństwa wielkopolskiego w pierwszej połowie XV wieku, Ecclesia. Studia z dziejów Wielkopolski 5, 2010.

Dallari U., I rotuli dei lettori legisti e artisti dello studio bolognese dal 1384 al 1799, t. I, Bologna 1888.

Dembiński P., Poznańska kapituła katedralna schyłku wieków średnich. Studium prozopograficzne 1428-1500, Poznań 2012.

219 Przebadana została twórczość tylko niektórych kanonistów krakowskich, jak Stanisław ze Skarbimierza, Paweł Włodkowic, Mikołaj z Błonia i Jan Elgot, z których żaden nie studiował jednak w Bolonii (zob. K. O ż ó g, Uczeni, s. 51-52). 
Denifle H., Die Statuten der Juristen-Universität zu Padua vom Jahre 1331, Archiv für Literatur- und Kirchengeschichte des Mittelalters 6, 1892.

Derwich M., Stanisław z Wojczyc i benedyktyni łysogórscy, Acta Universitatis Nicolai Copernici, Historia XXVI, Nauki Humanistyczno-Społeczne, z. 240 (1992).

Diario bolognese di Mo Gaspare Codibó dal 1471 al 1504, con note e cronotassi dei priori e cappellani di Santa Maria Maddalena in Bologna, wyd. A. Macchiavelli, Bologna 1915 (Biblioteca de „L'Archiginnasio”, ser. II, nr 9).

Dola K., Wrocławska kapituła katedralna w XV wieku. Ustrój, skład osobowy, działalność, Lublin 1983.

Fijałek J., Polonia apud Italos scholastica saeculum XV, z. 1, Cracoviae 1900.

Frova C., M. Miglio, „Studium Urbis” e „Studium Curiae” nel Trecento e nel Quattrocento: linee di politica culturale, w: Roma e lo Studium Urbis. Spazio urbano e cultura dal quattro al seicento, Roma 1992 (Publicazioni del Archivio di Stato, Saggi 22).

Gallo D., Lauree inedite in diritto civile e canonico presso lo Studio di Padova (1419-1422, 1423, 1424, 1428), Quaderni per la storia dell’Univerità di Padova 20, 1987.

Garbacik J., Górka (z Górki) Uriel, w: Polski słownik biograficzny, t. VIII (1959).

Gargan L., L'enigmatico „,conduxit”. Libri e dogana a Padova fra Tre e Quattrocento, Quaderni per la Storia dell'Università di Padova 16, 1983.

Gąsiorowski A., Dobrogost z Lwówka, w: Polski słownik biograficzny, t. XXIV (1979).

Gąsiorowski A., Kanonicy włocławscy w najstarszej metryce kapitulnej (1435-1500), w: Duchowieństwo kapitulne w Polsce średniowiecznej i wczesnonowożytnej, Toruń 2000.

Gąsiorowski A., Panowie z Ostroroga. Wprowadzenie, w: Wielkopolscy Ostrorogowie, Ostroróg 1998.

Gąsiorowski A., I. Skierska, Średniowieczni oficjałowie gnieźnieńscy, Roczniki Historyczne $61,1995$.

Girgensohn D., Gli statuti medioevali delle Università di giurisprudenza italiane: conservazione, materie regolate, interdipendenze, w: Università in Europa. Le istituzioni universitarie dal Medio Evo ai nostri giorni. Strutture, organizzazione, funzionamento, Soveria Mannelli 1995.

Góralski W., Wkład kapituły katedralnej w Płocku do rozwoju kultury umysłowej miasta do XVI wieku, Studia Płockie 32, 2004.

Górski K., Studenci z Prus w Bolonii w XIV i XV wieku, Komunikaty Mazursko-Warmińskie 1989, $\mathrm{nr} 1-4$.

Grendler P., The Universities of the Italian Renaissance, Baltimore-London 2002.

Hajdukiewicz L., Lubrański Jan, w: Polski słownik biograficzny, t. XVIII (1973).

Hornowska M., H. Zdzitowiecka-Jasieńska, Zbiory rękopiśmienne w Polsce średniowiecznej, Warszawa 1947.

Koczerska M., Zbigniew Oleśnicki i Kościół krakowski w czasach jego pontyfikatu (14231455), Warszawa 2004.

Kodeks dyplomatyczny Wielkopolski, t. IX, wyd. A. Gąsiorowski, T. Jasiński, Warszawa-Poznań 1990.

Kot S., Le relazioni secolari della Polonia con la Bologna. Conferenza tenuta il 9 gennaio 1948 nell'Accademia delle Scienze dell'Istituto di Bologna, Bologna 1949.

Kowalczykówna M., Pniowski Jan, w: Polski słownik biograficzny, t. XXVII (1983).

Kowalska-Pietrzak A., Prałaci i kanonicy kapituły łęczyckiej do schyłku XV wieku, Łódź 2004.

Kowalski M. D., Dlaczego warto było zostać kolektorem? Kariery papieskich kolektorów generalnych w Polsce XV wieku, Roczniki Historyczne 80, 2014.

Kowalski M., Proventus camerae apostolicae debiti. Opłaty duchowieństwa polskiego na rzecz papiestwa w latach 1417-1484, Kraków 2010.

Kozłowska-Budkowa Z., Polonia w Bolonii w latach 1300-1327, w: Cultus et cognitio. Studia z dziejów średniowiecznej kultury, Warszawa 1976.

Kozłowska-Budkowa Z., Zawodzińska C., I primi studenti polacchi all'università di Bologna (fino al 1364), w: Commentationes historicae. Almae Matri Studiorum Bononiensi novem secula feliciter celebranti ab Universitate Iagellonica Cracoviensi oblatae, Cracovia 1988. 
Królik L., Kapituła kolegiacka w Warszawie do końca XVIII wieku, Warszawa 1990.

Lewański R., La matricola degli scolari polacchi a Bologna: un tentativo di ricostruzione e di analisi, w: Laudatio Bononiae, Bologna-Varsavia 1990.

Lewański R., Storia delle relazioni fra la Polonia e Bologna, Bologna 1951.

Liber decanorum facultatis philosophicae Universitatis Pragensis ab anno Christi 1367 usque ad annum 1585, Pragae 1830-1832 (Monumenta Universitatis Carolo-Ferdinandae Pragensis, t. I/I).

Liber secretus iuris caesarei dell’Università di Bologna, wyd. A. Sorbelli, t. I: 1378-1420, Bologna 1938.

Liber secretus iuris caesarei dell'Università di Bologna, wyd. A. Sorbelli, t. II: 1421-1450 con una introduzione sull'esame nell'Università durante il Medioevo, Bologna 1942.

Liber secretus iuris pontifici dell’Università di Bologna 1451-1500, wyd. C. Piana, Milano 1989.

Lichończak-Nurek G., Wojciech herbu Jastrzębiec, arcybiskup i mąż stanu (ok. 1362-1436), Kraków 1996.

Lichończak-Nurek G., Wojciech Jastrzębiec i jego rodzina, w: Cracovia - Polonia - Europa. Studia z dziejów średniowiecza ofiarowane Jerzemu Wyrozumskiemu w sześćdziesiątą piątą rocznicę urodzin i czterdziestolecie pracy naukowej, Kraków 1995.

Malagola C., I Polacchi in Bologna, w: Bologna. Album storico, Bologna 1882.

Metryka Uniwersytetu Krakowskiego z lat 1400-1508. Biblioteka Jagiellońska rkp. 258, Kraków 2004.

Minucci G., Le lauree dello Studio Senese alla fine del secolo XV, Milano 1981.

Monumenta Polonorum Bononiensia, Bologna 1964.

Najstarsza księga promocji Wydziału Sztuk Uniwersytetu Krakowskiego z lat 1402-1541, wyd. A. Gąsiorowski, T. Jurek, I. Skierska, Warszawa 2011.

Nowacki J., Brudzewski Mirosław, w: Polski słownik biograficzny, t. III (1937).

Ochmański J., Biskupstwo wileńskie w średniowieczu. Ustrój i uposażenie, Poznań 1972.

Orlandelli G., Bartolomeo da Saliceto, w: Dizionario biografico degli Italiani, t. VI (1964).

Ostroróg Jan, w: Polski słownik biograficzny, t. XXIV (1979).

Ożóg K., Piotr Wolfram, w: Profesorowie Wydziału Prawa Uniwersytetu Jagiellońskiego, t. I, Kraków 2015.

Ożóg K., Uczeni w monarchii Jadwigi Andegaweńskiej i Władysława Jagiełły (1384-1434), Kraków 2004.

Ożóg K., Wojciech Jastrzębiec, w: Profesorowie Wydziału Prawa Uniwersytetu Jagiellońskiego, t. I, Kraków 2015.

Петришак В., Кар’єри публічних нотаріїв у Львові XV-XVI ст, Średniowiecze Polskie i Powszechne 3 (7), 2011.

Piana C., Il „Liber secretus iuris caesarei” dell'università di Bologna 1451-1500, Milano 1984.

Piana C., Lauree in diritto civile e canonico conferite dall'Università di Bologna secondo la relazione del „Liber sapientum” (1419-1434), Atti e memorie della deputazione della Storia Patria per le province di Romagna 17-19, 1969.

Piana C., Nuovi documenti sull'Università di Bologna e sul Collegio di Spagna, t. I-II, Bologna 1976.

Piana C., Ricerche su le Università di Bologna e di Parma, Firenze 1963.

Pini A., Scolari ricchi e scolari poveri tra medioevo ed età moderna, w: Studio, università e città nel medioevo bolognese, Bologna 2005.

Pio B., La peregrinatio academica nell'età dello scisma: studenti di diritto canonico a Bologna fra XIV e XV secolo, w: Identità cittadine e aggregazioni sociali in Italia, secoli XI-XV, Trieste 2012.

Pio B., Oldrendi Giovanni (Giovanni da Legnano), w: Dizionario biografico degli italiani, t. LXXIX (2013).

Pio B., Lo Studium e il Papato tra XIV e XV secolo, w: Politica e 'Studium': nuove prospettive e ricerche, Bologna 2005 (Studi e memorie per la storia dell’Università di Bologna, seria nowa, t. 10). 
Poniewozik L., Prałaci i kanonicy sandomierscy w okresie średniowiecza, Torun 2004.

Prokop K. R., Biskupi kijowscy obrządku łacińskiego XIV-XVIII w. Szkice biograficzne, Biały Dunajec - Ostróg 2003.

Przeździecki A., O Polakach w Bononii i Padwie, Warszawa 1853.

Radzimiński A., Prałaci i kanonicy kapituły katedralnej płockiej w XIV i I poł. XV w. Studium prozopograficzne, t. I-II, Toruń 1991-1993.

Repertorium Germanicum, t. V, wyd. H. Diener, Tübingen 2004.

Rossetti L., Spunti per la storia degli scolari polacchi a Bologna e a Padova, w: Laudatio Bononiae, Bologna-Varsavia 1990.

Rył J., Biblioteka katedralna w Gnieźnie, Archiwa, Biblioteki i Muzea Kościelne 23, 1976.

Schuchard C., Die Deutschen an der päpstlichen Kurie im späten Mittelalter (1378-1447), Tübingen 1987 (Bibliothek des Deutschen Historischen Instituts in Rom 65).

Schwarz B., Kurienuniversität und stadtrömische Universität von ca. 1300 bis 1471, Leiden 2012 (Education and Society in the Middle Ages and Renaissance 46).

Słowikowski T., Giżycki Zygmunt, w: Polski słownik biograficzny, t. VIII (1959-1960).

Sobociński W., Memoriał Jana Ostroroga a początki reformacji w Polsce, Odrodzenie i Reformacja w Polsce 4, 1959.

Sorbelli A., Storia dell’Università di Bologna, t. I: Il Medioevo (secoli XI-XV), Bologna 1940.

Sroka S. A., Academic degrees obtained by Poles studying at northern Italian universities in the second half of the 15 th c. (Bologna, Padua, Ferrara), Annali di Storia delle università italiane 2013.

Sroka S. A., Doktoraty Polaków na uniwersytecie w Ferrarze w pierwszej połowie XVI wieku, Roczniki Historyczne 80, 2014.

Sroka S. A., Dyplom doktorski Uniwersytetu Bolońskiego z 1472 r., Studia Źródłoznawcze 50, 2012.

Sroka S. A., Polacy w Bolonii u schyłku średniowiecza w świetle diariusza Gaspare Codibó z lat 1471-1504, w: Memoria viva. Studia historyczne pamięci Izabeli Skierskiej, Warszawa-Poznań 2015.

Sroka S. A., Szydłowiecki Paweł, w: Polski słownik biograficzny, t. XLIX (2013-2014).

Sroka S. A., Wykaz Polaków wypromowanych na uniwersytecie w Bolonii w drugiej połowie XV w., Kwartalnik Historyczny 131, 2014, nr 1.

Statuti delle Università e dei Collegi dello Studio Bolognese, wyd. C. Malagola, Bologna 1888.

Stolarczyk T., Oporowscy herbu Sulima. Kariera rodziny możnowładczej w późnośredniowiecznej Polsce, Łódź 2013.

Stopka K., Szkoły katedralne metropolii gnieźnieńskiej w średniowieczu. Studia nad kształceniem kleru polskiego w wiekach średnich, Kraków 1994.

Sułkowska-Kurasiowa I., Polska kancelaria królewska w latach 1447-1506, Wrocław 1967.

Szacherska S. M., Mikołaj z Mirzyńca, w: Polski słownik biograficzny, t. XXI (1976).

Szymczakowa A., Szlachta sieradzka w XV wieku. Magnifici et generosi, Łódź 1998.

Tamba G., Chartularium Studii Bononiensis. Riflessioni su un'esperienza quasi secolare, w: La storia delle università italiane. Archivi, fonti, indirizzi di ricerca, Trieste 1996.

Translatio Sancti Floriani, wyd. W. Kętrzyński, w: Monumenta Poloniae historica, t. IV, Lwów 1884.

Trombetti-Budriesi A. L., L'esame di laurea presso lo Studio bolognese. Laureati in diritto civile nel secolo XV, w: Studenti e università degli studenti. Dal XII al XIX secolo, Bologna 1988.

Uruszczak W., Wydział Prawa Uniwersytetu Krakowskiego i jego profesorowie w latach 1364-1780, w: Profesorowie Wydziału Prawa Uniwersytetu Jagiellońskiego, t. I, Kraków 2015.

Vetulani A., Średniowieczne rękopisy płockiej biblioteki katedralnej, Roczniki Biblioteczne 7, 1963, z. 3-4.

A. Vetulani, Z badań nad Polakami w średniowiecznej Bolonii, w: Cultus et cognitio. Studia z dziejów średniowiecznej kultury, Warszawa 1976. 
Voisé W., Doktryna polityczno-prawna Jana Ostroroga, Państwo i Prawo 6, 1954.

Wendehorst A., Das Bistum von Eichstätt, t. I, Berlin - New York 2006 (Germania Sacra, Neue Folge 45).

Weysenhoff-Brożkowa K., Marcin ze Słupcy, w: Polski słownik biograficzny, t. XIX (1974).

Wiesiołowski J., Kolekcje historyczne w Polsce średniowiecznej XIV-XV wieku, Wrocław 1976.

Wiesiołowski J., Ostroróg Jan, w: Wielkopolski słownik biograficzny, Warszawa-Poznań 1981.

Wiesiołowski J., Sędziwój z Czechła. Studium z dziejów kultury umysłowej Wielkopolski, Studia Źródłoznawcze 9, 1964.

Windakiewicz S., Bolonia i Polska, Przegląd Polski 22, 1888 (t. 88), z. 10.

Windakiewicz S., Informacja o aktach uniwersytetu bolońskiego, w: Archiwum do dziejów literatury i oświaty w Polsce, t. VII, Kraków 1892.

Windakiewicz S., Materiały do historii Polaków w Padwie, Archiwum do dziejów literatury i oświaty w Polsce, t. VII, Kraków 1892.

Wiśniewski J., Katalog prałatów i kanoników sandomierskich od 1186 do 1926 r., tudzież sesje kapituły sandomierskiej od 1581 do 1866 r., Radom 1926.

Wójcik-Zega D., Jan z Wysokiej, w: Profesorowie Wydziału Prawa Uniwersytetu Jagiellońskiego, t. I, Kraków 2015.

Wyczański A., Memoriał Jana Ostroroga a postulaty egzekucyjne XVI wieku, w: Ludzie, Kościół, wierzenia. Studia z dziejów kultury i społeczeństwa Europy Środkowej (średniowiecze - wczesna epoka nowożytna), Warszawa 2001.

Wyrozumska B., Grzegorz Cieniawa, w: Polski słownik biograficzny, t. IX (1960-1961).

Wyrwa T., Les idées politiques et juridiques de Jan Ostroróg, humaniste polonais du XVe siècle, Revue Historique de Droit Français et Étranger, ser. 4, t. 53, 1975, nr 1.

Zdanek M., Adam z Będkowa, w: Profesorowie Wydziału Prawa Uniwersytetu Jagiellońskiego, t. I, Kraków 2015.

Zdanek M., Grzegorz Cieniawa z Mysłowic, w: Profesorowie Wydziału Prawa Uniwersytetu Jagiellońskiego, t. I, Kraków 2015.

Zdanek M., Jan Pniowski z Pniowa, w: Profesorowie Wydziału Prawa Uniwersytetu Jagiellońskiego, t. I, Kraków 2015.

Zwiercan M., Piotr z Krakowa, w: Polski słownik biograficzny, t. XXVI (1981).

\section{Juristische Doktorgrade von Polen in Bologna des 15. Jahrhunderts}

\section{Zusammenfassung}

Der Beitrag stellt eine Gruppe von 29 Polen vor, die im Laufe des 15. Jahrhunderts den Grad eines Lizenziaten oder eines Doktors der Rechte erreichten (ihre Herkunft, ihr Alter bei der Graduierung in Bologna, ihre Studien an anderen Universitäten, ihre weiteren Karrieren). Die Analyse der Biogramme dieser Polen im Vergleich zu den Berichten der Libri secreti der Doktorenkollegien der Juristen deutet darauf hin, daß ungefähr die Hälfte von ihnen wegen der Graduierung nach Bologna kam und kein volles Rechtsstudium absolvierte bzw. die rechtliche Bologneser Formation erreichte, unter der man ein genau definiertes, unter dem Einfluß mehrjähriger Jurastudien in Bologna geformtes rechtliches Wissen und die dabei erworbenen Erfahrungen und Gewohnheiten verstand. Diejenigen Polen, bei denen von mindestens einer teilweisen Bologneser Formation gesprochen werden kann, stammten in der Regel aus reichen und mächtigen Geschlechtern und gelangten zu Anfang ihrer jeweiligen Karriere und in recht jungen Jahren nach Bologna. Die Vertreter der zweiten Gruppe standen im reifen Alter, sie besaßen Pfründen und bekleideten wichtige kirchliche und staatliche Ämter. In der Regel studierten sie in Bologna nur kurz. In der zweiten Hälfte des 15. Jahrhunderts ist unter den in 
Bologna studierenden und entsprechende wissenschaftliche Grade erwerbenden Polen besonders das Umfeld der Domstifte Posen, Gnesen und Płock vertreten, während das Krakauer Milieu vergleichsweise schwach ist.

Übersetzt von Waldemar Könighaus

\section{Doctorates in law of Poles in Bologna in the 15th century}

\section{Abstract}

The article describes a group of 29 Poles who received a licentiate or doctorate in law in the fifteenth century (their origins, age at the time of graduation in Bologna, studies at other universities, careers). The purpose is to show different ways of receiving a degree at Bologna (as a result of full studies or just coming over to get the degree) and to name those graduates in whose cases one can speak of the Bolognan legal formation.

Translated by Rafat T. Prinke 